\title{
Morphological priming resists language and modality switching in late Dutch-Brazilian Portuguese bilinguals
}

\section{Priming morfológico resiste em face à alternância entre línguas e modalidades com bilíngues tardios de holandês e português brasileiro}

\author{
Marije Soto \\ Universidade do Estado do Rio de Janeiro, Rio de Janeiro, Rio de Janeiro / Brasil \\ marijesoto@hotmail.com
}

\author{
Aline Gesualdi Manhães \\ Centro Federal de Educação Tecnológica Celso Suckow da Fonseca, Rio de Janeiro, \\ Rio de Janeiro / Brasil \\ alinegesualdi@gmail.com
}

\begin{abstract}
In this study, we aimed to investigate how late bilinguals of Dutch and Brazilian Portuguese (BP) engage in morphological processing in L2. Morphologically related and unrelated word pairs combined with cross-linguistic and cross-modal variations were presented in a lexical decision experiment in order to compare morphological priming effects in L 2 and L1. We collected both reaction times and Event Related Potentials (ERPs). In L2, morphological priming effects were observed in lower amplitudes for the N400 component, but no effect was observed for RT measures. This can be explained under the assumption that the N400 component is more sensitive to lexical properties of roots (e.g. $\sqrt{\text { friend }}$ ) than to lexical properties of full word forms (e.g. friendliness). We consider that difficulties in L2 morphological processing are not necessarily due to a lack of parsing of morphemic units, but because of
\end{abstract}


the difficulty in the semantic interpretation of derivational morphemes in L2. This occurs via compositional mechanisms that are grammatically constrained, which are especially difficult to acquire in adult life. This is in line with what is suggested by the Superficial Processing Hypothesis (CLAHSEN et al., 2010). Moreover cross-linguistic priming showed that although morphological priming occurred for switching from L2 to L1, it caused the opposite effect for switching from L1 to L2. These results confirm predictions made by the Revised Hierarchical Model (KROLL et al., 2010), which explains this type of data in terms of the relative weakness of concept to word form mapping in L2 as compared to word form to concept mapping.

Keywords: switching; bilingual word recognition; N400.

Resumo: Neste estudo, pretende-se investigar o processamento morfológico em bilíngues tardios de holandês (L1) e português brasileiro (L2). Pares de palavras morfologicamente relacionados e pares não relacionados foram apresentados em uma tarefa de decisão lexical com alternância de línguas e de modalidade entre prime e alvo a fim de comparar efeitos de priming morfológico na L1 e na L2. Coletamos tempos de resposta (TRs) e Potenciais Relacionados a Eventos (ERPs). $\mathrm{Na}$ L2, efeitos de priming morfológico foram observados nas amplitudes reduzidas do componente do N400, mas nenhum efeito foi observado para os TRs. Isso pode ser explicado, se considerar que o N400 é mais sensível às propriedades lexicais das raízes (ex. Vamigo) do que às propriedades lexicais das palavras inteiras (ex. amigável). As dificuldades no processamento morfológico na L1 não são necessariamente devidas a uma falha na segmentação dos morfemas, mas devido à dificuldade para interpretar os morfemas derivacionais semanticamente. Isso depende de mecanismos composicionais que são guiadas pelas regras morfológicas que são especialmente difíceis para serem adquiridas durante a vida adulta. Essa conclusão está de acordo com a Hipótese de Processamento Superficial (CLAHSEN et al., 2010). Ainda, a alternância entre línguas evidenciou que, embora houvesse priming morfológico para a direção de L2 para L1, para a direção de L1 para L2 o efeito oposto ocorreu. 
Esses resultados confirmam as previsões lançadas pelo Modelo Revisado Hierárquico (KROLL et al., 2010), que explica esse tipo de dado em termos da fragilidade relativa na L2 do mapeamento do significado da palavra para a sua forma lexical comparada ao mapeamento da forma lexical para seu significado.

Palavras-chave: acesso lexical bilíngue; alternância; N400.

Recebido em 13 de dezembro de 2016

Aprovado em 7 de maio de 2017

\section{Introduction}

The agility with which bilinguals alternate freely between lexical items in different languages is truly an amazing feat of human cognition. Yet it is part of everyday life for the majority of people in the world. A conservative estimate of about $50 \%$ of the world population (BHATIA; WILLIAMS, 2005) operates easily in both monolingual and bilingual mode $^{1}$ and engages in code switching ${ }^{2}$ on a daily basis. This has led many researchers to raise questions about how the bilingual lexicon is

\footnotetext{
${ }^{1}$ According to Grosjean (1989), the mode in which bilinguals activate L1 and L2 refers to whether both languages are equally activated (bilingual mode), or asymmetrically activated (monolingual mode). The mode in which the bilingual operates depends on the information he or she receives in the form of expectancy, pragmatic context, or task instructions.

${ }^{2}$ Code Switching is a typical phenomenon among bilingual speakers. It consists of inserting excerpts of speech in one language, in a conversation structured in another language. For a long time, this phenomenon was understood as a way to compensate for some deficiency in proficiency in one of the dominant languages of the bilingual speaker. The hypothesis was that when bilingual speakers engage in code switching, it is to compensate for some aspect they do not master in one of their native languages by inserting words of the other, a phenomenon known as semilingualism (LIPSKY., 1978; HEREDIA; BROWN, 2004). Currently, it is believed that Code Switching involves pragmatic competence of bilinguals which enables them to recognize bilingual conversational partners of the same languages, thus sharing in common linguistic competence and cultural identity (MEISEL, 1994).
} 
organized, the manner in which lexical representations are activated, and the nature of the processing mechanisms operating on the comprehension and production of lexical items in monolingual and bilingual modes. Essential to these questions is also how factors such as age of acquisition, exposure, cultural identity, among others, influence these aspects.

In this study, we focus on whether and how late bilinguals engage in morphological processing in L2. With regards to this, the main issues under debate are the following: (i) is there any morphological processing in L2 for late bilinguals, and if so, is it comparable to L1 morphological processing?; (ii) are (morphological) processing strategies dependent on L1 characteristics? (for example, if L1 is morphologically 'rich' in comparison to L2, does this lead to deeper L2 morphological processing?); (iii) does L2 morphology map onto meaning as readily as L1 morphology does, or is it mostly mediated by lexical representations in L1? (BRAESBART; DIJKSTRA, 2006; PORTIN et al., 2007; LEMHÖFER et al., 2008; DIEPENDAELE et al., 2011). We approached these questions by investigating morphological priming ${ }^{3}$ in late bilinguals who are native speakers of Dutch (their dominant language), having learned Brazilian Portuguese as adults $(>21 \mathrm{y})$ while living in Brazil. We adhere to Grosjean's definition of bilinguals. He defines bilinguals as individuals who use two languages in their daily life (GROSJEAN, 1994). To tap into the processing mechanisms of this group of bilinguals we collected both neurophysiologic and behavioral data, using Event Related Potential (ERP) ${ }^{4}$ and priming methodologies. There are very few

\footnotetext{
${ }^{3}$ In a word priming paradigm, different types of relations between prime (1st word) and target (2ndword) are manipulated, such as: semantic association (apple-pear), morphological relation (teach-teacher), phonologic similarity (peach-pea), repetition(peach-peach), to name a few. The rationale behind this paradigm is that the activation of the second word is affected (facilitated or hindered) by the activation of the previously presented word (the prime). Depending on the research hypothesis, a specific kind of relation can be manipulated in order to assess its involvement in word representation and processing.

4 Event Related brain Potentials (ERPs) are extracted from continuous Electroencephalogram (EEG) recordings in which stimulus presentation onset is marked so that the signal can be segmented to study neurophysiological responses to stimuli. Segments are added and averaged per experimental condition so that they may be compared for experimental condition effects. This is measured by comparing amplitudes (in voltage) and latencies (moment of maximum peak in ms) in a given time interval. An N400 component is thus a negative amplitude peak approx. 400ms after stimulus onset, a P300 effect is a positive peak approx. $300 \mathrm{~ms}$ after stimulus onset.
} 
studies on morphological priming in bilinguals using ERP methodology, and none of them comparing Dutch-Brazilian Portuguese bilinguals. Therefore, as a pioneer contribution to the field, this study might raise more questions than it answers, as there are as of yet not many data to compare with in literature.

In order to address the specific question of morphological processing in L2, participants had to engage in a lexical decision task, presenting morphologically related pairs (ex. friend-friendly) and unrelated pairs (ex. pencil - garden) as the control condition in both L1 and L2. Facilitation of lexical access by morphological priming as compared to a control baseline has been attested both in monolinguals and bilinguals (DIJKSTRA et al., 2005; PORTIN et al., 2007; SILVA; CLAHSEN, 2008; DOMINGUEZ; SEGUÍ; CUETOS, 2002), and -as an experimental effect- can be isolated from phonological, orthographical and semantic priming effects (DE GROOT; DELMAAR; LUPKER, 2000; DIJKSTRA et al., 1999). Target words that are morphologically related to their primes (e.g. teach-teacher) are recognized faster compared to targets in orthographically or phonologically related pairs (e.g. freezefree), and semantically related pairs (e.g. horse-farm) (DIEPENDAELE et al., 2011). This specific facilitation effect indicates that morphological information is an integral and influential part in the architecture of the lexicon, both for monolinguals and bilinguals. However, the manner in which morphology operates in bilingual comprehension, in mono or bilingual mode, is still a matter of debate.

Although morphological priming effects have been shown in several studies with bilinguals, researchers are not conclusive in the interpretation of the results. A study by Diependaele et al. (2011) showed that Spanish-English and Dutch-English bilinguals, who had started learning English from the ages of 18 and 12, respectively, displayed similar reaction times as English monolinguals in a masked morphological priming experiment in which participants had to perform a lexical decision task in English(L2). Some authors claim data such as these suggest that bilinguals largely adopt the same processing strategies in L2 as monolingual native speakers of that language (LEMHÖFER et al., 2008). If this is indeed the case, it means that morphological processing in L2 involves parsing words for morphemic units and that recognition of morphologically complex words is guided by rule based automatic processing, analogue to L1 processing. Contrary to this idea, 
other authors suggest that bilinguals rely more heavily on whole-word processing in their second language than in their first language. In this case a stored representation of a whole-word is accessed, while morphological composition within words remains opaque (ULLMAN, 2004, 2005; CLAHSEN et al., 2010). Data that point in this direction are presented by Hahne et al. (2006). Their study showed that late bilinguals use morphological decomposition strategies to process morphological derivation with suffixes, such as in bitter-bitterness, but not to process inflectional morphology, either for regular or irregular verbs. ${ }^{5}$ Some authors take this to be evidence that derivational and inflectional processes have differential cognitive status, given that the latter depends on interpretation of functional categories, such as tense features, for which L2 grammar representation may not contain the same level of detailing as compared to L1 grammar (ULLMAN, 2004, 2005; HAHNE et al., 2006; CLAHSEN et al., 2010).

In this view, lack of detailing in L2 grammar occurs when L2 is learned after childhood or, for some authors, after puberty. For Ullman $(2004,2005)$ this idea is based on his declarative/procedural model. In this model, word recognition can occur via direct lexical retrieval or via compositional mechanisms that are grammatically constrained. The former relies on declarative memory, subserved by the left temporal lobe, and the latter on procedural memory, which engages the left frontal cortex and basal ganglia. Rule based automatic procedures are acquired early in life, and, thus, do not support language learning after childhood. This implies that late bilinguals are more dependent on declarative memory for L2 representations, and, therefore, are biased

\footnotetext{
${ }^{5}$ Most commonly morphemes are understood to be of two categories: (i) derivational; or (ii) inflectional. Derivational morphemes add to the meaning of a root, affecting both category and meaning (ex. to judge (v)-judgment (n)), and morphological rules supposedly determine which combinations between roots and morphemes are grammatical (ex. - ment combines with a specific group of verbs). Inflectional morphemes do not change the category of the word they combine with, but indicate syntactic or semantic relations between constituents of sentences. For example, the present tense morpheme $-s$ indicates agreement between a verb and its $3^{\text {rd }}$ person subject. However, there are authors that contest the cognitive relevance of the derivational vs. inflectional distinction, given that there are some morphemes that share characteristics of both types (e.g. a participle morpheme can both nominalize and inflect in BP) (MARANTZ, 1997)
} 
for whole-word representations. Some authors associate this supposed inability for deep grammatical processing in late bilinguals as a logical consequence of cognitive-biological limitations for language acquisition beyond the critical period (HAHNE; FRIEDERICI, 2001). Other authors stress the possibility of the development of proficiency over time, even for late learners, which greatly attenuate effects of so-called superficial processing (HAHNE et al., 2006; KOTZ et al., 2004).

The reduced ability for acquiring rule based automatic procedures for late bilinguals supposedly leads to an L2 grammar that is morphologically underspecified, consequently only enabling 'superficial' processing (Superficial Processing Hypothesis, CLAHSEN; FELSER, 2006; CLAHSEN et al., 2010). Thus, the functioning of the morphological parser in bilinguals is expected to yield overall slower and less automatized processing, especially for late L2 learners, who supposedly rely more heavily on memory and attention for L2 processing than for L1 processing (ULLMAN, 2004; 2005). Mostly this rationale is built on evidence showing bilinguals process derivational morphology differently from inflectional morphology. Nonetheless, criticism on this rationale is that morphological priming results in bilinguals mostly resemble monolingual data, which also tend to show stronger morphemic priming with derivations than with inflections (FELDMAN, 1994; SCHRIEFERS; FRIEDERICI; GRAETZ, 1992; SILVA; CLAHSEN, 2008). That is why, in this study we chose to focus only on the stimuli with derivational suffixes.

Based on data from the literature, an effect for morphological priming for late bilinguals in both L1 and L2 is expected, especially if the stimuli only present derivational morphemes. On the other hand, morphological processing might be relatively superficial for L2 as compared to L1, due to late acquisition of L2. If this affects parsing across the board, RTs might be reduced for targets in L2.

To ensure that potential morphological priming in L2 is not merely due to an orthographic form repetition effect, participants were presented with trials in which modality was varied. Primes were presented in either auditory or written form, while targets were always written. In lexical decision tasks, auditory stimuli generate reduced amplitudes for ERPs and faster RTs, reflecting ease of processing as compared to written stimuli (STOCKAL; MARANTZ, 2006). Yet in this study, primes will be varied for modality, while all targets will be written. In the case of 
cross-modal priming pairs, a switching cost is generated, as evidenced by slower RTs and slower N400 effects in comparison to unimodal priming (HOLCOMB et al., 2005; KIYONAGA et al., 2007).

Proficiency levels in late bilinguals affect both RT measures and ERP data. ERP studies show that proficient L2 speakers tend to present similar neurophysiologic responses as native speakers of that language (KOTZ et al., 2008). The N400 component can appear in both less and more proficient L2 speakers. This ERP signature is generally associated with semantic processing, and it also sensitive to morphological processing. Facilitation of access to target words as a result of morphological or semantic priming yields lower amplitudes $400 \mathrm{~ms}$ after word presentation onset as compared to targets of unrelated word pairs. Generally, the lower amplitudes are interpreted as reflecting a relative ease in processing (OSTERHOUT et al., 1997; MUNTE et al., 1999; KUTAS; FEDERMEIER, 2000; PYLKKÄNEN et al., 2000; 2003; DOM et al., 2004; MARANTZ, 2005; FRANÇA et al., 2008; LAU et al., 2008; SOTO, 2010; GARCIA et al., 2012). Differences in proficiency may correlate with subtle modulations in latency and amplitude of the N400 component.

Even speakers with relatively low proficiency can present N400 responses to semantic priming. However, very few studies have looked into bilingual morphological priming with ERP methodologies. Components that supposedly reflect (morpho)syntactic processing, such as ELAN and P600, generally only appear in very proficient speakers (KOTZ, 2001; DIJKSTRA et al., 2005; HAHNE; FRIEDERICI, 2001). Nonetheless, P600 waveforms can appear in proficient late bilinguals when processing L2, and they may resemble those of native speakers of that same language. Hahne et al. (2006) presented participants with inflected verbs (past tense) and nouns (plural) in L2 in a syntactic violation paradigm, which yielded a P600 effect, and not an earlier ELAN component. The authors took this to as a confirmation of the aforementioned claim that bilinguals process inflectional morphology different from derivational morphology. Factors that influence resemblance to native-like responses for N400 and P600 components are proficiency (TANNER et al., 2016), age of acquisition (KOTZ et al., 2008) and the degree of similarity of the tested syntactic property between L1 and L2 (DIAZ et al. 2016). In this study, we would expect reduced N400 amplitudes for targets in morphologically related pairs as compared to targets in unrelated word pairs. The degree of this 
morphological priming effect on the N400 components might reflect the proficiency and stage of acquisition of the group of late bilinguals.

Another hypothesis, put forth by Díaz et al. (2016) as well as Portin et al. (2007), is that language specific traits might influence both RT and ERP measures. Portin et al. (2007) discuss whether language specific morphological traits influence processing strategies. They suggest that native speakers of languages that are known to be morphologically complex, such as Finnish, which boasts 200 possible declinations for nouns alone, apply similar processing strategies on languages that display relatively less rich derivational and inflectional morphology, such as English. The authors claim that bilingual native speakers of Finnish will display a tendency to use morphological decomposition for L2 word recognition because their native language has 'sculpted' processing mechanisms. This view, stemming from a weaker version of the Linguistic Relativity thesis (WHORF, 1956; BORODITSKY, 2003) would predict that perhaps Dutch L1 speakers are biased for monomorphemic and monosyllabic words (e.g. tuin, ("garden")) and productive compounding processes (e.g. tuin-man, ("garden-man -> gardener")). Derivational morphemes are productive in Dutch (e.g. vriend - vriendelijkheid, ("friend - friendliness"), but compounding is far more common in word formation. On the other hand, compounding as a word forming process is rare in BP, which is why all targets (in L1 as well as L2) in this study are words with two or more derivational morphemes. An L1 bias in this group of Dutch-BP speakers might make them less likely to engage in processing mechanisms that are inherent to morphologically rich languages such as Brazilian Portuguese (BP). If this is case, than contrary to our initial prediction, morphological priming effects in L2(BP) might be weak or even absent, meaning that RTs and N400 will show little difference with those in response to unrelated pairs.

Another way of investigating morphological processing in L2 is to test whether L2 morphemes map onto meaning just as readily as L1 morphemes do. In order to examine this, we included cross-linguistic morphological priming in both directions: prime L1-target L2, and prime L2-target L1. There is now a large amount of data in the literature on bilingual word recognition that steadily points to bilingual lexical access as being non-selective for either L1 or L2. This means that in the first stages of auditory and visual word recognition, in principle, word candidates from the different languages may compete (JACKET; 
FRENCH, 2002; BRYSBAERT; DIJKSTRA, 2006; KROLL et al., 2010). This notion is reflected by the various hypotheses of how the bilingual lexicon is organized. Traditional models for bilingual word recognition, such as the one proposed by Paradis (1997), propose language-specific storage for word forms (orthographic and phonological forms with their syntactic properties) and word meanings, with a conceptual non-linguistic level shared by both languages.

The idea of a separation between language-dependent lexical meaning storage and a conceptual level shared by two languages is still present in more recent models, such as the Revised Hierarchical Model (RHM) (DE GROOT, 1998; KROLL; DE GROOT, 1997; KROLL et al., 2010). Yet the focus has shifted to the notion of two lexicons that are functionally separate, rather than a physical or organizational separation for the storage of bilingual lexicons. Moreover, data indicate that parallel activation to lexical and sublexical information between languages occur (KROLL et al., 2010). The question is thus if meaning activated by a word in L1 (ex. vriend ("friend")) can prime a root in a morphologically more complex word in L2 (ex. Vamigo+(a)vel ("friend + ly")), provided that the root is a translation candidate of the word in L1, and vice versa. The RHM, although more intended as a model for word prediction than word recognition, foresees that L1 and L 2 can both map onto conceptual representations, but that links between L2 word forms and concepts are weaker. More specifically, the RHM hypothesizes that in L2, the strength of links in the direction of concept to word form is weaker than that for the opposite direction, from word form to concept. This may cause asymmetric effects in the sense that, for late bilinguals, access from words to concepts may be accomplished easily, while access from concepts to words may demand more effort. Under this assumption, RHM would predict facilitation from L2 to L1 (L2L1: amigo-vriendelijk ("friend-friendly")), given that the L2 word form amigo readily maps onto a conceptual representation, which has rich links to L1, thus, easily priming morphologically related candidates. Additionally, there might be a parallel link connecting the word amigo directly to the word form of a translation pair (e.g. vriend). Yet, language switching in the other direction (L1L2: vriend-amigável ("friend-friendly")) would be expected to make target recognition more difficult due to the fact that the L1 word easily maps on to a conceptual representation, which might be widely connected to an array of conceptual representations that link to 
other lexical representations in L1. Not only would these compete with any upcoming word in L2, but mapping from concept to form might be more difficult in L2. Added to this asymmetric effect is that even if the conceptual features are shared, access to these features via word form, might not be equivalent for L1 and L2, especially if bilinguals are less proficient, for example (KROLL et al., 2010). Therefore, if the RHM is correct in its predictions, for this study, we might expect facilitation to hold when there is a switch between prime and target language, depending on the switching condition. Facilitation is expected for L 2 to L1, whereas slow processing is expected for L1 to L2.

However, not all studies have shown evidence of asymmetric cost, especially not in word recognition tasks. For word recognition, there is not necessarily a need to select among competitors, especially if the task is to merely acknowledge the word as being a potential word in either L1 or L2, such as is the case in this experiment. Also, in this study, bilinguals are consciously triggered into bilingual mode because monolingual priming pairs (L1L1 or L2L2) are alternated with bilingual pairs (L1L2 or L2L1) and they are told to recognize words in either L1 or L2. Therefore, the cognitive effort spent on inhibiting L1 competitors may be reduced (BRYSBAERT; DIJKSTRA, 2006). There are also other factors that may reduce asymmetric switching effects. The strengthening of links between L2 word forms and conceptual representations may evolve as bilinguals gain more proficiency.

ERP data for morphological processing in monolinguals present evidence that word recognition is compositional, given that N400 components are sensitive to lexical properties of roots (e.g. $\sqrt{\text { friend }}$ ) more so than lexical properties of the full word form (friendliness). This suggests that N400 responses may reflect access to the stored meaning representation as activated by a given lexical root, and that subsequent processing of derivational suffixes is of relatively low cost, not reflected by N400 amplitudes, perhaps since it only adds highly predictable and systematized meaning to an already accessed meaning (e.g. . Vfriend + ly (attribute) + -ness (state of)) (PYLKKÄNEN et al., 2000, 2002, 2003; FRANÇA, et al., 2008).

In the case of cross-linguistic morphological priming, the prime and target are related by way of translation pairs that supposedly map on to shared conceptual features. For example, if the prime is vriend (L1 ("friend")), it may map on to amigo (L2 ("friend")), which is the 
lexical root of the morphologically more complex target amigável (L2 ("friendly")). An N400 component measured during the presentation of a target in L2 probably reflects facilitation due to the sustained activation of the meaning representation as accessed by the prime vriend. If we assume that the lexical root in L2 and translation pair of the prime amigo is easily identified within the morphologically complex target by morphological parsing, its mapping onto an already activated meaning should yield facilitation effects. However the posterior process of parsing (in this example: amig-(a)vel) and additional processing of derivational suffixes might be more costly in L2 than it is in L1. This might be caused by less efficient morphological parsing in L 2 or by difficulty mapping the suffixes onto meaning, as well as a reduced richness in the representation of morphologically related word forms in the L2 lexicon. All of these factors might make it more difficult to recognize a morphologically complex target word in L2, even if it is primed by a morphologically related word in L1. Thus, while N400 components may show facilitation effects, reaction times may not due to these additional difficulties in the case of L1 to L2 switching. In the ERP literature opposite effects between behavioral results and N400 components are not uncommon (HAHNE; FRIEDERICI, 2001; HAHNE et al., 2006, KOTZ, 2001; KOTZ; ELSTON-GÜTTLER, 2004; WEBER-FOX; NEVILLE, 1996), since these measures may reflect different stages in word recognition, or be affected differently by experimental task requirements.

According to the predictions of the RHM, as well as the Superficial Processing Hypothesis, an asymmetric switch effect is expected, but for different reasons. The RHM predicts that relatively weaker links between word forms and concepts in L2 will result in slower RTs for morphological priming, especially when the direction of the switch is from L1 to L2. The Superficial Processing Hypothesis foresees overall less efficient morphological processing for L2, which may also lead to an asymmetric switch effect from L1 to L2, but it also predicts no or reduced morphological priming for non-switch priming in L2. 


\section{The experiment}

In this study we presented morphologically related and unrelated word pairs in order to compare morphological priming effects in L2 and L1. Facilitation for morphologically related targets relative to unrelated target controls in L2 would be evidence of effective morphological processing in late bilinguals of Dutch and Brazilian Portuguese (BP). Participants engaged in a lexical decision task, for which they had to decide whether targets were words either in Dutch or in BP. In order to present an equal number of trials with possible yes or no answers, we added trials with Hungarian targets, a language none of the participants had been exposed to before. We collected EEG measures and reaction times(RTs) from 18 proficient late bilinguals. Faster RTs and lower mean amplitudes of the N400 component reveal facilitation effects for morphological priming as compared to unrelated prime and target pairs.

Besides, non-switch trials (L1 to L1 and L2 to L2), participants were also presented with switch trials (L2 to L1 and L1 to L2). With the switch condition, we aimed to test whether L2 morphemes map onto meaning just as readily as L1 morphemes do. The lexical root contained in a morphologically complex target word may be primed by a prime if it is a translation candidate (e.g. prime: vriend (L1 ("friend")) - target: Vamig-(a)vel/ amigável, ("friend-ly")). The Revised Hierarchical Model foresees that the switch direction from L1 to L2 is more costly because in L2 the links from concept to word form might be weaker than those mapping word forms to concepts. The Superficial processing hypothesis (CLAHSEN; FELSER, 2006; CLAHSEN et al., 2010) foresees overall less efficient morphological processing for L2, which may also lead to an asymmetric switch effect from L1 to L2, but it also predicts no or reduced morphological priming for non-switch priming in L2. Asymmetric priming effects as well as slower overall processing for L2 in general may be reflected by relatively slower RTs as compared to L1 targets, or absence of any morphological priming. However, N400 amplitudes may yield evidence for facilitation, even when RTs do not, if we assume that N400 components sensitive to lexical properties of roots (e.g. V friend) than to lexical properties of full word forms (e.g. friendliness).

Finally, to ensure that the morphological priming effects are not merely a case of an orthographic repetition effect, we added a crossmodal variable, presenting trials with auditory primes followed by written targets, as well as trails for which both prime and target were written. For both types of trials, morphological priming effects may be expected. 


\section{1 Materials and Methods}

The four variables in our study are: (i) relation type: morphological vs. unrelated; (ii) switch: switch vs. non-switch; (iii) target language: L1(Dutch) vs. L2(BP); (iv) modality: auditory vs. written. These combinations yielded 16 conditions. In Table 1, conditions and sample stimuli are presented except for those including Hungarian $(\mathrm{H})$ targets. There were four conditions with Hungarian targets: $\mathrm{L} 1 \mathrm{H}$ and $\mathrm{L} 2 \mathrm{H}$, both with auditory and written primes. Modality conditions are not specified in Table 1, but of all of the 8 conditions were presented with auditory primes and written primes, reaching a total of 16 conditions. Each condition was represented by 8 items, and an equal number of pairs with Hungarian targets were added for the purposes of the lexical decision task. In total, 256 pairs were presented to each participant (for the complete list, see Appendix 1).

The auditory stimuli were recorded by native speakers for L1 and L2, both speakers were female and matched for pitch. We controlled words for frequency over all conditions by using a hit count in Google, ${ }^{6}$ and equally distributed the number of items for all the grammatical classes of the primes $(\mathrm{L} 1$ : noun $=83$; $\operatorname{adj}=25$; verb $=20$ and L2: noun=82; $\operatorname{adj}=25$; verb $=21$ ), and targets (L1: noun=30; $\operatorname{adj}=32$; verb $=2$, and L2: noun $=34 ; \operatorname{adj}=25 ; \operatorname{verb}=3$; adverb=2). We distributed a controlled variety of suffix types over all conditions, presenting at least 2 items for each suffix type (L1: 9 different suffixes and L2: 14 different suffixes) (see Appendix 2 for a complete list). Also, we controlled for number of phonemes, presenting a range of 4-6 for primes, and 6-8 for targets. In terms of morphological complexity, primes were always composed of a root and a category morpheme (e.g. amig $+o$, ("friend")), and the target was always a morphologically complex word with 2 or more morphemes (e.g. amig $+a+$ vel, ("friendly") or vriend $+($ e) lijk + heid, ("friendliness")). Stimuli were pseudo-randomized and divided into two

\footnotetext{
${ }^{6}$ In the absence of large corpora for Brazilian Portuguese, we chose to run a Google search for each word in the stimuli set. Frequency is measured by the number of Google hits for .br sites on a given day. It is perhaps not an ideal but an acceptable indication of surface frequency in the absence of large accessible corpus with the appropriate information codification. Google hits filter out infrequent words such as drupa ('blossom') with 24.500 hits vs. flor ('flower) with 10.400 .000 hits or coturno (lumberjack) 955.000 hits vs. bota ('boot') with 5.360 .000 hits
} 
lists. Eight participants from a previous Dutch-BP bilingual study who did not participate in this experiment were asked to judge all Portuguese words for familiarity. They were told to mark words as either known, unknown, or I'm not sure what this word means. None of the items were rejected unanimously; however, out of all the 176 Portuguese words, there were nine items which were marked as unknown by three volunteers. Notwithstanding, given that only one of these nine items was marked twice, we did not exclude any items.

TABLE 1 - Experimental design: experimental design and prime-target examples

\begin{tabular}{|c|c|c|c|}
\hline \multirow{2}{*}{ switch: } & \multirow{2}{*}{$\begin{array}{l}\text { prime-target } \\
\text { relation: }\end{array}$} & \multicolumn{2}{|c|}{ target $\mathrm{L}$ : } \\
\hline & & Dutch (L1) & Brazilian Portuguese (L2) \\
\hline \multirow{2}{*}{ switch } & morph.related & $\begin{array}{l}\text { jogo-SPELER } \\
\text { (“game-GAMER”) }\end{array}$ & $\begin{array}{l}\text { sluiten-FECHAMENTO } \\
\text { (“close-CLOSURE”) }\end{array}$ \\
\hline & unrelated & $\begin{array}{l}\text { rotina -VRIENDIN } \\
\text { ("routine-GIRLFRIEND") }\end{array}$ & $\begin{array}{l}\text { winnen-GRÁVIDA } \\
\text { (“win-PREGNANT”) }\end{array}$ \\
\hline \multirow{2}{*}{$\begin{array}{l}\text { Non- } \\
\text { switch }\end{array}$} & morph.related & $\begin{array}{l}\text { moeder-MOEDERLIJK } \\
\text { (“mother-MOTHERLY”) }\end{array}$ & $\begin{array}{l}\text { casar-CASAMENTO } \\
\text { ("wed-WEDDING") }\end{array}$ \\
\hline & unrelated & $\begin{array}{l}\text { vraag - PLEZIER } \\
\text { (“question-PLEASURE") }\end{array}$ & $\begin{array}{l}\text { burro - SEGURO } \\
\text { (“dumb-INSURANCE”) }\end{array}$ \\
\hline
\end{tabular}

\subsection{Participants}

In this study we take bilinguals to be individuals who make use of two languages in their daily life (GROSJEAN, 1994). Eighteen participants took part in the experiment, but 2 datasets were excluded due to artifacts and excessive noise on the EEG signals. One participant was excluded from the analysis based on proficiency scores. Thus, 15 datasets were included in the analysis. All participants had lived in Brazil for an average of 6,8 years (ranging from 4 to 18 years) and had thus been exposed to BP for the extent of that period. Participants varied in 
age from 25 to 48 years. None of the participants had been exposed to PB under the age of 21 .

All participants reported that L1(Dutch) was their dominant language. L2 Proficiency varied somewhat between participants, but before partaking in the experiment, participants were asked to describe some images in a Monica e sua turma comic book, the results of which were recorded and post-hoc assessed by 3 independent judges (native speakers of L2, and graduate students of the Language Faculty at the Federal University of Rio de Janeiro). The judges used a three-point scale to assess participants on pronunciation, vocabulary, and fluency, and a five-point scale for structure. Most participants scored between 2 and 3 points for pronunciation and vocabulary and around 4 points for structure (see Appendix 4 for all results). One participant was excluded based on proficiency scores, which were far below the grades of the other participants, achieving only $50 \%$ for fluency and vocabulary.

Some biographic data were collected also (see Appendix 3). All participants had started learning Portuguese after the age of 21 and additionally spoke another foreign language (English, French, German, and Spanish were the languages mentioned), a possible confound which is hard to avoid when dealing with Dutch bilinguals. All participants held at least bachelor degrees, except for two participants who finished preparatory scientific education. All participants were right-handed and had normal or corrected to normal vision. Also, none of the participants reported having any hearing impairments. All participants signed a form of consent which had been pre-approved by the Ethical Committee of the University Hospital of the Federal University of Rio de Janeiro.

\subsection{Procedure}

Participants were placed at a $90 \mathrm{~cm}$ distance in front of a 15 inch screen on which words were presented in Times New Roman font, size 25, on a black screen (see Figure 1 for the presentation protocol) using Presentation software version 12.2 (developed by Neurobehavioral Systems). The lexical decision task was first explained, and participants were instructed to use a button box to respond, pressing a green button for YES and a red button for NO, only judging the target. Left and right positions of buttons were alternated between participants. There was a training session of 15 trials, which was repeated if participants did not 
understand the task correctly. During the experiment, there were four breaks during which participants could continue at their own leisure. Total time of recording, including electrode placement and proficiency testing, was approximately 1.5 hours.

The presentation protocol of the stimuli is shown in Figure 2. A low pitched tone marked the beginning of each trial, accompanied by a fixation cross. Primes and targets were each presented for $200 \mathrm{~ms}$ separated by masking for $250 \mathrm{~ms}$. Primes alternated for either sound or written form. After target presentation, there was a $1500 \mathrm{~ms}$ time out period during which participants carried out the lexical decision task.

FIGURE 1 - Presentation protocol: presentation protocol for the priming paradigm as presented on the Presentation platform. The last screen presents the target for which the participant has to perform the lexical decision task

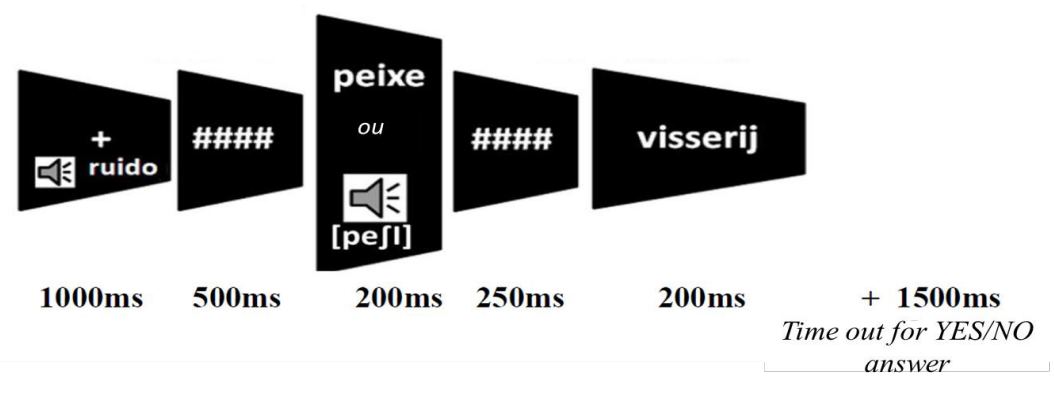

Before starting the experiment, 21 electrodes were placed on the participant's head according to the international 10-20 set up (see Figure 2) (NIEDERMEYER; SILVA, 1982). Silver cup electrodes were fixed to the scalp with electrolyte paste (Elefix by Nihon Kohden). Two electrodes placed on the left and right earlobes served as reference. Impedance was kept below $10 \mathrm{k} \Omega$ throughout the experiment. The EEG equipment used was BrainNet BNT 36, and EEG signals were filtered during the recording session $(100 \mathrm{~Hz}$, and $0,1 \mathrm{~Hz})$, sampling frequency was $200 \mathrm{~Hz}$. 
FIGURE 2 - Electrode set up: The photo shows a participant from the study to illustrate electrode placement according to standard 10-20 configuration
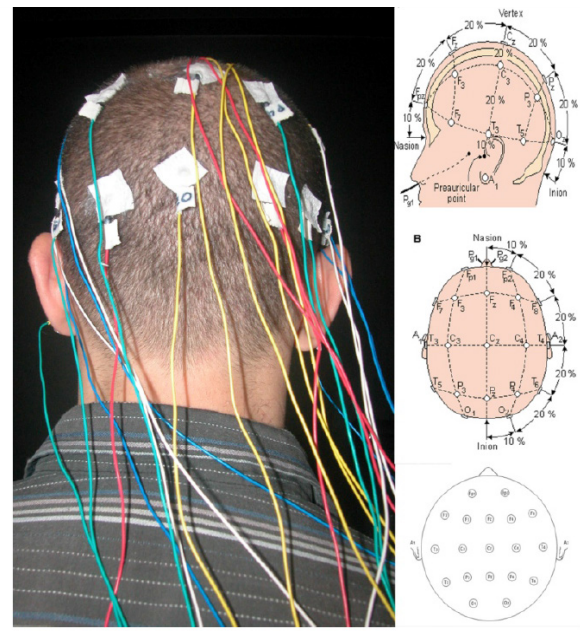

\section{Data processing and analysis}

Reaction times were recorded using the Presentation platform, and later on analyzed for normal distribution (Mauchly's Test of Sphericity). A cut off of $95 \%$ accuracy rate was determined a priori, but since all the participants achieved 95\% accuracy or over, none of the datasets were rejected. All trials were included in the analysis, except for outliers with a Z-score higher than 3 or lower than -3. RTs were analyzed using a four-way ANOVA Repeated Measures analysis in SPSS software, version 20. RTs were analyzed for all experimental variables: (i) switch; (ii) relation type; (iii) target language; and (iv) modality. RTs in response to Hungarian were not included in the analysis because they were not considered relevant to the issues under investigation.

Raw EEG signals were digitalized and processed in BrainVision Analyzer (BVA) software, version 2. Due to excessively noisy EEG signals, two datasets were excluded from the analysis. From the processed ERP wave forms (filtered at $30 \mathrm{~Hz}$, baseline correction $200 \mathrm{~ms}$ ) we extracted mean amplitudes over a predetermined interval of $350-450 \mathrm{~ms}$ after word presentation onset. The mean amplitude analysis requires that an a priori time interval is chosen from which all data points are taken into account to calculate a mean. In this experiment, sampling frequency was $200 \mathrm{~Hz}$, which means that within the $350-450 \mathrm{~ms}$ interval 20 data points 
yield one mean amplitude value (in $\mu \mathrm{V}$ ). Extracting mean amplitudes is considered a more reliable method than extracting only one maximum amplitude, based on the highest amplitude within a given time interval. This is because, in the averaging of the individual segments that form the final ERP wave forms, distorting can occur due to variability among items and subjects. Therefore, it is more relevant to look at all the data points within an interval as opposed to only 1 (maximum) data point (LUCK, 2005).

Based on anatomic region, electrodes with similar anatomic lobe reference were pooled into one Region of Interest (ROI) by the BVA pooling function, yielding the following ROIs: Frontal (F3,F4,F7,F8,Fz); Central (C3, C4,Cz); Temporal (T3,T4,T5,T6), Parietal (P3,P4,Pz), and Occipital $(\mathrm{O} 1, \mathrm{O} 2, \mathrm{Oz})$. Mean amplitude values were exported, and analyzed in SPSS (version 20), applying a five-way ANOVA Repeated Measures analysis. Mean amplitudes were analyzed for all experimental variables: (i) switch; (ii) relation type; (iii) target language; and (iv) modality, including (v) ROI (Frontal, Central, Temporal, Parietal, and Occipital) as a variable. For all ANOVA analyses, $p$ values of $<0.05$ were considered statistically significant.

\section{Results}

\subsection{Behavioral Data: results}

RTs were analyzed using a four-way ANOVA Repeated Measures analysis for the variables: (i) switch: switch x non-switch; (ii) relation type: morphological vs. unrelated; (iii) target language: L1 vs. L2; and (iv) modality: auditory $\mathrm{X}$ written. Main effects were found for all variables except relation type $(\mathrm{F}(1,118)=0.082, \mathrm{p}=0.776)$. The main effect for the target language variable $(F(1,118)=150.48, p<0.001)$ revealed that overall L1 rendered fastest RTs: both for non-switch $703.66 \mathrm{~ms}(163.21 \mathrm{~ms})$ and for switch $708.38 \mathrm{~ms}(169.71 \mathrm{~ms})$ conditions. Post-hoc pairwise comparisons (LSD) showed there was no significant difference between the two conditions $(\mathrm{p}=0.60)$. Overall L2 as a target language yielded slower RTs: for non-switch $766.12 \mathrm{~ms}(7.78 \mathrm{~ms})$ and for switch $793.61 \mathrm{~ms}(7.78 \mathrm{~ms})$. There was a significant difference between the conditions with a p-value of 0,008. Differences between target languages L1 and L2, irrespective of the switching condition, were always significant with $\mathrm{p}$-values of $<0,001$. The main effects for the switch variable $(F(1,118)=7.53, p=0.007)$ revealed overall slower RTs for the switching condition (non-switch: $734.99 \mathrm{~ms}(5.89 \mathrm{~ms})$ vs. switch: $750.99 \mathrm{~ms}(5.98 \mathrm{~ms}))$. However, as the interaction between the effects of 
Target language and switch variables indicates (Target L. vs. Switch: $\mathrm{F}(1,118)=5.33, \mathrm{p}=0.023)$, switching from L1 to L2 yielded the slowest RTs $(793.61 \mathrm{~ms}(7.78 \mathrm{~ms}))$. The main effect for modality $(\mathrm{F}(1,118)=28.64$, $\mathrm{p}<0.001)$ was reflected by overall significantly slower RTs for targets followed by auditory primes as compared to written primes (AUD: $766.15 \mathrm{~ms}(5.41 \mathrm{~ms})$ vs. WR: $721.05 \mathrm{~ms}(5.14 \mathrm{~ms}, \mathrm{p}<0.001)$.

Various interactions were also found: switch $\mathrm{X}$ target language: $\mathrm{F}(1,118)=5.33, \mathrm{p}=0.023$; switch $\mathrm{X}$ relation type $\mathrm{F}(1,118)=9.45, \mathrm{p}=0.003$; target X relation type: $\mathrm{F}(1,118)=7.84, \mathrm{p}=0.006$; and switch $\mathrm{x}$ relation type $\mathrm{x}$ modality: $\mathrm{F}(1,118)=4.79, \mathrm{p}=0.031$. To interpret these interactions in more detail, RTs for relation type and modality variables are presented for all prime-target language combinations in Graph 1. RT values for morphologically related targets are presented in red, while RT values for unrelated pairs are presented in blue.

GRAPH 1 - Reaction times for variables relation type and modality per language combination: RTs for targets preceded by an auditory prime presented on the left (AUD) of each graph; RTs for targets preceded by written primes are presented on the right of each graph. RTs for morphological pairs are presented in blue; RTs for unrelated pairs are presented in red. Graphs a and $b$ present RTs for the non-switch condition with L1 and L2 as target languages, respectively; Graphs c and d present RTs for the switch condition with L1 and L2 as target languages, respectively

a: L1 to L1

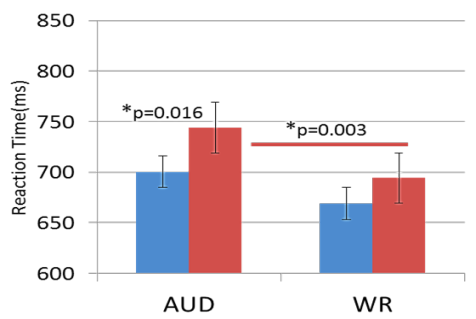

c: $\mathbf{L 2}$ to $\mathbf{L 1}$

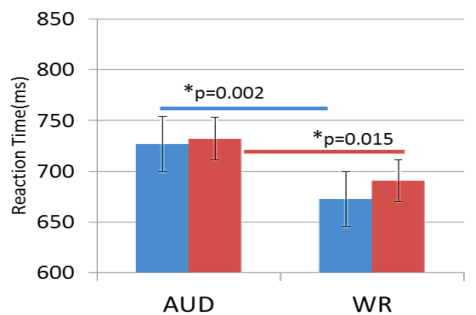

b: L2 to L2

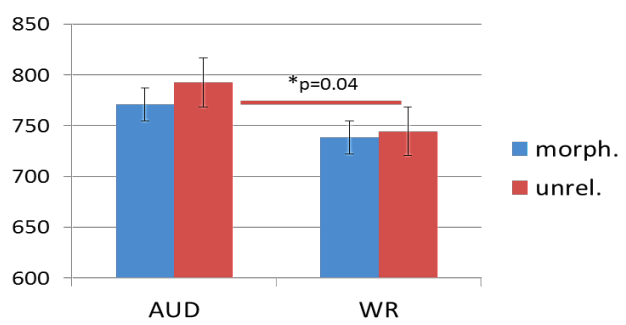

d: L1 to $\mathbf{L 2}$

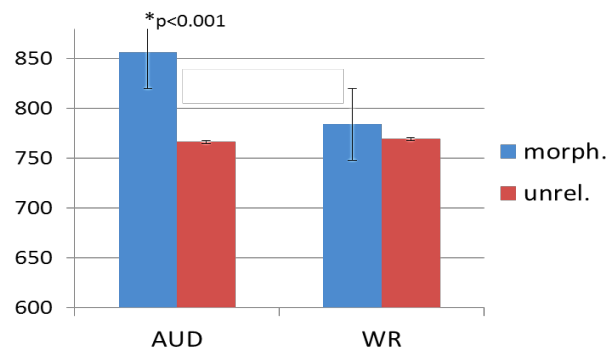


In Graph 1a, we can see that there was a statistically significant morphological priming effect for the non-switch condition with L1 as the target language, i.e. L1 to L1 priming, and only when the prime was auditory. The priming effect was expressed by faster RTs for morphologically related targets as compared to unrelated targets: morph. $700.44 \mathrm{~ms}(161.41 \mathrm{~ms})$ vs. unrel. $744.21 \mathrm{~ms}(150.77 \mathrm{~ms})$, with p-value of $\mathrm{p}=0.016$. For all other language combinations in different modality combinations there was no statistically significant effect (for all pairwise comparisons see Table 2).

For the switch direction L1 to L2 in the auditory condition, morphologically related targets yielded far slower RTs than for unrelated targets (see Graph 1b): morph. 856.49ms(204.24ms) vs. unrel. $766.60 \mathrm{~ms}(176.50 \mathrm{~ms}), \mathrm{p}<0.001$.

For most language combinations, targets preceded by auditory primes yielded slower RTs than targets preceded by written primes, especially when unrelated targets are compared, with statistically significant values for L1 to L1 ( $p=0.003)$, L2 to L2 ( $p=0.048)$, and, L2 to L1 (0.015). RTs for auditory modalities also yielded slower RTs as compared to written modalities for morphological pairs, but only in the switch conditions: L1 to L2 (AUD. $726.69 \mathrm{~ms}(183.01 \mathrm{~ms})$ vs. WR. $672.61 \mathrm{~ms}(156.54 \mathrm{~ms}), \mathrm{p}=0.015$, and L2 to L1 (AUD. $726.69 \mathrm{~ms}(183.01 \mathrm{~ms}$ ) vs. WR. $672.61 \mathrm{~ms}(156.54 \mathrm{~ms}), \mathrm{p}=0.340$. In the latter switch condition, the apparent difference was not significant statistically, probably due to relatively high standard error values as visualized by the errors bars in Graph 1d. 
TABLE 2 - Pairwise comparisons for relation type and modality variables per language combination: Reaction times are given in ms with standard error between parentheses. P values were calculated for pairwise comparisons applying an LSD test

\begin{tabular}{|c|c|c|c|c|c|}
\hline & \multirow[t]{2}{*}{ L prime - L target } & \multirow{2}{*}{$\begin{array}{l}\text { relation } \\
\text { type }\end{array}$} & \multicolumn{2}{|c|}{$\begin{array}{c}\text { modality } \\
\text { (RTs in ms) }\end{array}$} & \multirow[t]{2}{*}{$p$ value } \\
\hline & & & AUD & WR & \\
\hline \multirow{6}{*}{$\begin{array}{l}\text { non- } \\
\text { switch }\end{array}$} & \multirow{3}{*}{$\mathrm{L} 1$ to $\mathrm{L} 1$} & morph. & $\begin{array}{c}700.44 \\
(161.42)\end{array}$ & $\begin{array}{c}669.01 \\
(163.15)\end{array}$ & 0.130 \\
\hline & & unrel. & $\begin{array}{c}744.12 \\
(150.77)\end{array}$ & $\begin{array}{c}694.19 \\
(165.31)\end{array}$ & \multirow[t]{2}{*}{$* 0.003$} \\
\hline & & $p$ values & $* 0.016$ & 0.236 & \\
\hline & \multirow{3}{*}{$\mathrm{L} 2$ to $\mathrm{L} 2$} & morph. & $\begin{array}{c}770.81 \\
(161.46)\end{array}$ & $\begin{array}{c}738.33 \\
(171.52)\end{array}$ & 0.096 \\
\hline & & unrel. & $\begin{array}{c}792.52 \\
(177.02)\end{array}$ & $\begin{array}{c}744.37 \\
(180.41)\end{array}$ & \multirow[t]{2}{*}{$* 0.048$} \\
\hline & & $p$ values & 0.312 & 0.773 & \\
\hline \multirow{6}{*}{ switch } & \multirow{3}{*}{$\mathrm{L} 2$ to $\mathrm{L} 1$} & morph. & $\begin{array}{c}726.69 \\
(183.01) \\
\end{array}$ & $\begin{array}{c}672.61 \\
(156.54) \\
\end{array}$ & $* 0.002$ \\
\hline & & unrel. & $\begin{array}{c}732.14 \\
(158.40)\end{array}$ & $\begin{array}{c}690.79 \\
(157.31)\end{array}$ & \multirow[t]{2}{*}{$* 0.015$} \\
\hline & & $p$ values & 0.766 & 0.351 & \\
\hline & \multirow{3}{*}{$\mathrm{L} 1$ to $\mathrm{L} 2$} & morph. & $\begin{array}{c}856.48 \\
(204.24)\end{array}$ & $\begin{array}{c}784.29 \\
(161.02)\end{array}$ & 0.340 \\
\hline & & unrel. & $\begin{array}{c}766.60 \\
(176.50)\end{array}$ & $\begin{array}{c}769.51 \\
(149.61)\end{array}$ & \multirow[t]{2}{*}{0.858} \\
\hline & & $p$ values & $*<0.001$ & 0.403 & \\
\hline
\end{tabular}

\subsection{Behavioral Data: conclusion}

The data show that this group of late bilinguals does not present any morphological priming effect in L2. It is difficult to say whether this effect can be explained by an overall slower processing in L2 or whether this is related specifically to difficulty processing morphologically complex words in L2. Both RTs for morphologically related and unrelated targets were equally slower in L2 as compared to L1. In L1 there was a facilitation effect due to morphological priming, but this was only 
statistically significant for targets that followed auditory primes. This seems to suggest that morphological priming occurs irrespective of an orthographic repetition effect, but this conclusion is tentative given that morphological priming only robustly occurred with cross-modal priming, thus offering no grounds for comparison with unimodal priming. Across the board, cross-modal conditions resulted in higher RTs, indicative of a cognitive cost.

There was also no cross-linguistic morphological priming. On the contrary, the highest RTs overall were in response to morphologically related targets preceded by auditory pairs in the L2 to L1 condition. Switching from L1 to L2 yielded higher RTs across all conditions, but the interesting point here is that RTs were significantly higher for morphologically related targets than for unrelated targets in the same language switching condition. This seems in line with what the Revised Hierarchical Model (RHM) would predict; namely, that relatively rich semantic features activated by L1 primes co-activate many L1 related candidates, but not an equal amount of L2 candidates, hindering lexical access in L2. For unimodal written pairs in the L1 to L2 direction, the difference between RTs for morphologically related and unrelated targets was not statistically significant, but there is a tendency towards an asymmetric effect also.

\subsection{ERP data: results}

In this analysis we will discuss mean amplitudes, measured in $\mu$ Volts, extracted from the ERP waveforms within the $350-450 \mathrm{~ms}$ interval after word presentation onset (LUCK. 2005). An ANOVA analysis for repeated measures was carried out, considering the following variables: (i) switch: non switch vs. switch; (ii) relation type: morphological vs. unrelated; (iii) target language: L1 vs. L2; (iv) modality: auditory vs. written; and (v) ROI: Frontal, Central, Temporal, Parietal, and Occipital. The analysis revealed main effects for relation type: $F(1,13)=18.21, p=0.001$, modality: $F(1,13)=13.18, p=0.003$, and $\operatorname{ROI}(4,52)=8.16, \mathrm{p}<0.001$. There were no main effects for the switch variable $(\mathrm{F}(1,13)=0.014, \mathrm{p}=0.91)$ and target language $(\mathrm{F}(1,13)=1.03$, $\mathrm{p}=0.33)$. There were no interactions between the variable ROI and any of the experimental variables (ROI vs. target L.: $F(4,52)=0.13, p=0.97$; 
ROI vs. mod: $\mathrm{F}(4,52)=0.53, \mathrm{p}=0.72$; ROI vs. rel.type: $\mathrm{F}(4,52)=1.44$, $\mathrm{p}=0.23$; ROI vs. switch: $\mathrm{F}(4,52)=0.75, \mathrm{p}=0.56$ ). The fact that there was no interaction between ROI and any of the variables, may be taken as an indication that the main effect of ROI as a variable is mostly caused by differences in the strength of the responses in different ROIs, rather than by any experimental effect that would be specific for only one of the ROIs. Reports in the literature cite central and parietal areas as most consistent for the N400 effect (KUTAS; FERERMEIER, 2000; LUCK, 2005; LAU et al., 2008). Therefore, both our analysis and findings in literature support the selection of the parietal ROI as representative for N400 effects in order to illustrate the results of our analysis.

An ANOVA analysis for repeated measures on mean amplitudes only from the Parietal ROI showed that main effects in this region mirror those described in the previous paragraph. In Graph 2, mean amplitude measures are shown for the 4 experimental variables. Negative amplitudes as compared to relatively less negative amplitudes or positive amplitudes are considered to reflect a higher cognitive cost. For example, for the modality variable there was a main effect $(\mathrm{F}(1,14)=7.79, \mathrm{p}=0.014$, which was driven by more negative amplitudes for targets preceded by written primes $(-10.11 \mu \mathrm{V})$ than for targets preceded by auditory primes $(9.06$ $\mu \mathrm{V})$. Thus, the data seem to suggest that the processing of written targets takes more cognitive effort relative to the processing of auditory targets. The main effect for relation type $(F(1,14)=14.84, p=0.002)$ revealed that overall targets of unrelated pairs elicited more negative amplitudes $(-6.55 \mu \mathrm{V})$ than targets of morphologically related pairs $(5.5 \mu \mathrm{V})$. There were no effects for the target language variable $(\mathrm{F}(1,14)=0.014, \mathrm{p}=0.91)$ nor for the switch variable $(\mathrm{F}(1.14)=0.08, \mathrm{p}=0.784)$, indicating that overall there were no significant differences between targets in L1 and L2, irrespective of the previous language context (L1 or L2). The lack of interaction between these variables confirms this interpretation $(\mathrm{F}(1,14)=0.78, \mathrm{p}=0.39)$. 
GRAPH 2 - Main effects for the parietal ROI: mean amplitudes in $\mu \mathrm{V}$ are shown for modality in blue, switch in purple, relation type in green and target language in orange

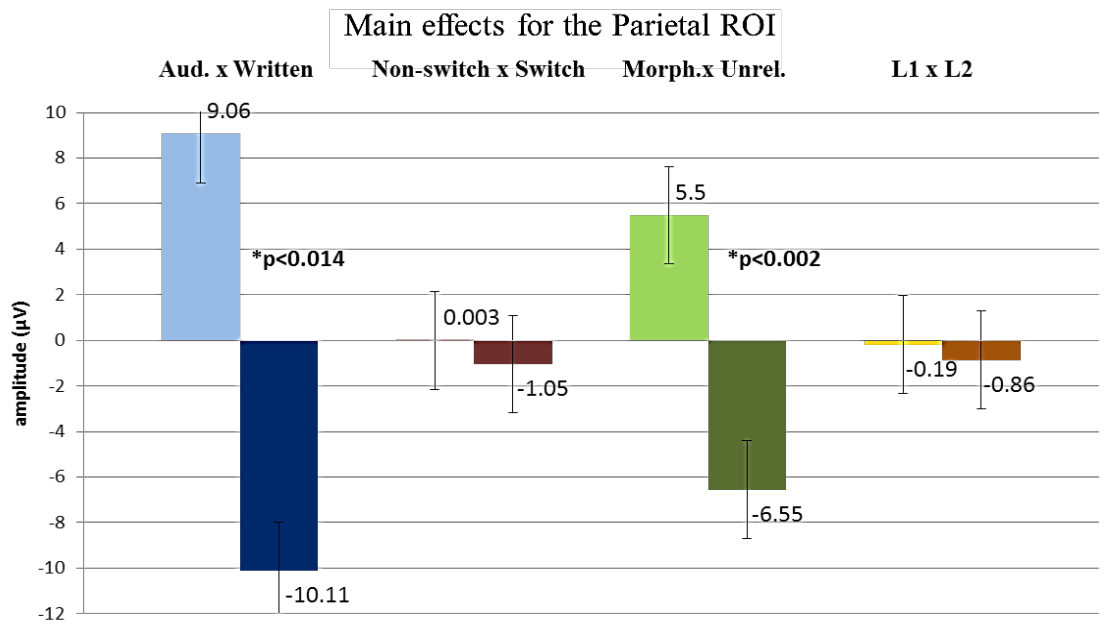

To examine the effects of the experimental conditions on the waveforms, Figures $3 \mathrm{a}$ and $\mathrm{b}$ are presented with ERPs for target language L1 (Fig. 3a) and L2 (Fig. 3b), collapsing switch and non-switch conditions so as to make the comparison between the four waveforms representing modality and relation type easier. There are two major peaks in these ERP graphs: the first peak around $170 \mathrm{~ms}-200 \mathrm{~ms}$, and a second around $400 \mathrm{~ms}$. Our analysis focuses on mean amplitudes extracted from the $350-450 \mathrm{~ms}$ interval as our interest is to examine the N400 component. Visual inspection of the waveforms in this interval (as marked by the shaded area) seems to suggest that there were priming effects for both L1 and L2, given that unrelated targets yielded higher amplitudes (i.e. more negative values, with negative values plotted upwards) as compared to morphologically related targets. This seems to be the case for targets preceded by auditory primes (black: morph vs. blue:unrel.) as well as for targets preceded by written primes (red: morph. vs. green: unrel.). The more negative (or less positive) amplitudes for unrelated targets in comparison to morphologically related targets may indeed imply there was a relative ease in processing as a consequence of morphological priming. However, post-hoc analyses (LSD) indicated that there was only 
a (nearly) statistically significant morphological priming effect for the cross-modal condition with L1 as the target language. For this condition, unrelated targets yielded higher (i.e. less positive) amplitudes as compared to morphologically related targets: $0.25(34.78)$ vs. $17.44 \mu \mathrm{V}(38.68 \mu \mathrm{V})$, $\mathrm{p}=0.05$. Perhaps qualitatively apparent morphological priming effects for other modalities with L2 as a target language are not robust enough to survive statistical analysis, which may be due to the fact that standard deviations are high, indicative of great variation in the data (for all values see Table 3).

FIGURE 3-ERPs for the Parietal ROI comparing Target Language - Waveforms for targets of morphologically related pairs are in black when preceded by an auditory prime, and in red when preceded by a written prime. Waveforms for targets of unrelated related pairs are in blue when preceded by an auditory prime, and in green when preceded by a written prime. The shaded area indicates the interval (350-450ms) from which mean amplitudes were extracted

ERPs of Parietal ROI: relation type vs. modality

a. Target L1

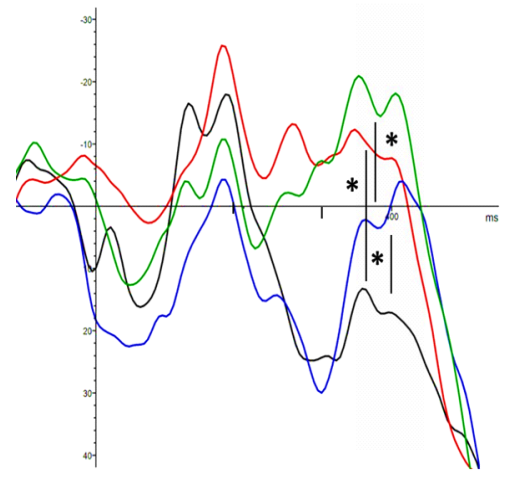

b. Target L2

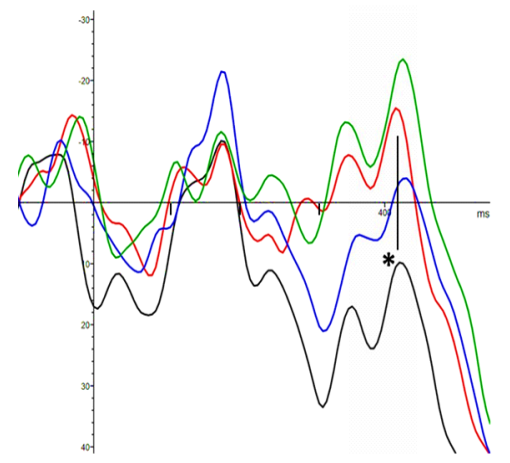

morph. AUD unrel. AUD morph. WR unrel. WR 
TABLE 3 - Post-hoc analysis of mean amplitudes for ERPs of the Parietal ROI: mean amplitudes indicated in $\mu \mathrm{V}$ with standard deviation in parentheses. Fisher's LSD (least significant difference) test was applied to carry out parewise comparisons

\begin{tabular}{l|l|l|l|l}
\hline $\begin{array}{l}\text { target } \\
\text { language }\end{array}$ & relation type & \multicolumn{2}{|c|}{ modality (values in $\mu \mathrm{V}($ std.dev) $)$} & \multicolumn{1}{|c}{$\begin{array}{c}\text { post hoc comparison } \\
\text { (LSD) }\end{array}$} \\
\cline { 3 - 5 } & & AUD & WR & p-value \\
\hline \multirow{2}{*}{ L1 } & morph.rel. & $17.44(38.68)$ & $-4.27(36.78)$ & 0.02 \\
\cline { 2 - 5 } & unrel. & $0.25(34.78)$ & $-14.18(42.07)$ & 0.03 \\
\cline { 2 - 5 } & p-value & 0.05 & 0.24 & \\
\hline \multirow{2}{*}{ L2 } & morph.rel. & $16.51(35.4)$ & $-7.67(41.36)$ & 0.02 \\
\cline { 2 - 5 } & unrel. & $2.05(45.45)$ & $-14.31(41.22)$ & 0.14 \\
\cline { 2 - 5 } & $p$-value & 0.12 & 0.37 & \\
\hline
\end{tabular}

Tendencies for morphological priming could be observed irrespective of cross-modal priming. In fact, for cross-modal priming, all amplitudes were lower, and differences between unrelated and morphologically related targets were greater; so much so that only crossmodal priming led to a statistically more pronounced effect for L1 targets. To investigate further whether morphological priming carried over even in switching conditions, all language combinations were plotted in Graph 4. Pairwise comparisons revealed that the morphological priming effect presented in Figure 3 for L1 as the target language were most likely driven by positive amplitudes for morphologically related targets in the L2 to L1 switching condition, but only in the cross-modal condition (L2 to L1: morph. $26.87 \mu \mathrm{V}(8.57 \mu \mathrm{V})$ vs. unrel. $-3.09 \mu \mathrm{V}(10.25 \mu \mathrm{V}), \mathrm{p}=0.009)$. Morphological priming for L2 as the target language reachednear significance with a $\mathrm{p}$ value of 0.06 for the L2 to L2 condition (morph. $13.23 \mu \mathrm{V}(9.58 \mu \mathrm{V})$ vs. unrel. $-5.88 \mu \mathrm{V}(11.35 \mu \mathrm{V}))$. This confirms the interpretation that there was a tendency for morphological priming, but that it was not statistically robust. The data suggest that morphological priming can occur in L2, even in a cross-linguistic context. Moreover, this effect does not rely on an orthographic repetition effect given that the morphological priming effect was restricted to cross-modal morphological priming pairs. 
For the L1 to L2 switching condition, there were no differences between the mean amplitudes of morphologically related and unrelated targets, but there was a statistically significant effect between unimodal and cross-modal priming, with more negative amplitudes for unimodal priming (morph.: AUD. $19.75 \mu \mathrm{V}(8.94 \mu \mathrm{V})$ vs. WR. $-21.27 \mu \mathrm{V}(10.95 \mu \mathrm{V})$, $\mathrm{p}=0.02$; and unrel.: AUD. $9.97 \mu \mathrm{V}(12.14 \mu \mathrm{V})$ vs. WR. $-17.35 \mu \mathrm{V}(8.80 \mu \mathrm{V})$, $\mathrm{p}=0.045)$. Cross-modal priming also led to differences in other language combinations (L1L1 and unrel.: AUD. $3.59 \mu \mathrm{V}(7.78 \mu \mathrm{V}$ ) vs. WR. $-19.51 \mu \mathrm{V}(9.56 \mu \mathrm{V}), \mathrm{p}=0.012$; and L2L1 and morph: AUD. 26.87 vs. WR:$6.0 \mu \mathrm{V}(10.6 \mu \mathrm{V}), \mathrm{p}=0.015)$. Nonetheless, it was in the L1 to L2 switching conditions that these differences were most pronounced since they could be observed between both morphologically related and unrelated pairs.

\subsection{ERP data: conclusions and comparison to RT data}

GRAPH 4 - Mean amplitudes for variables relation type and modality per language combination - Mean amplitudes for targets preceded by an auditory prime presented on the left (AUD) of each graph; Mean amplitudes for targets preceded by written primes are presented on the right of each graph. Mean amplitude values for morphological pairs are presented in blue, for unrelated pairs in red. Graphs $a$ and $b$ present mean amplitudes for the non-switch condition with L1 and L2 as target languages, respectively; Graphs $\mathrm{c}$ and d present mean amplitudes for the switch condition with L1 and L2 as target languages, respectively

a: L1 to L1

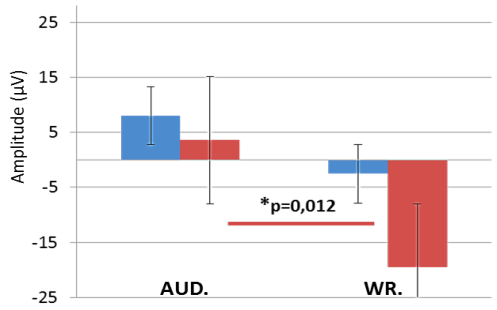

c: L2 to L1

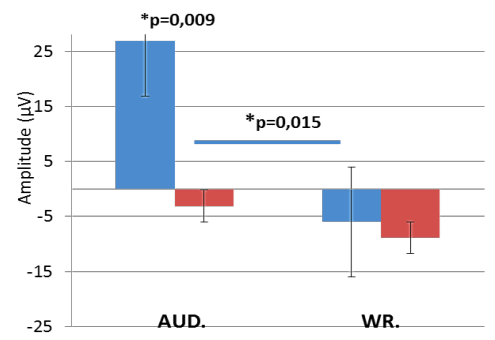

b: L2 to L2

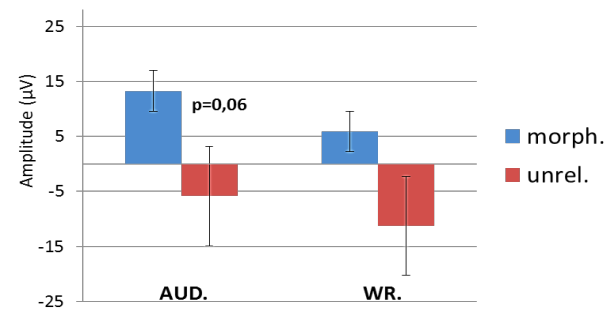

d: $\mathbf{L} 1$ to $\mathbf{L} 2$

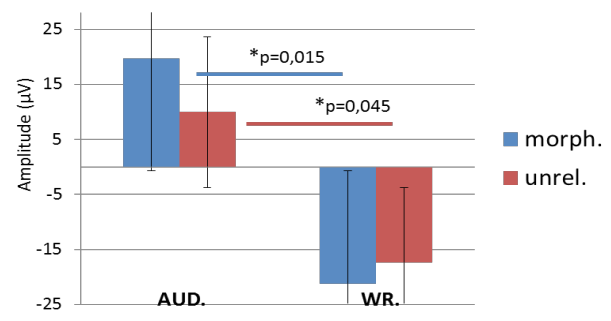


Lower amplitudes for morphologically related targets as compared to unrelated targets in the $350-450 \mathrm{~ms}$ interval indicated that there was an overall morphological priming effect for targets in L1. The fact that this facilitation was largest for switching from L2 to L1 suggests that L2 can successfully map onto meaning, thus, easily activating L1 translation pairs that prime morphologically related words in L1. Nearly significant morphological priming effects for the non-switch condition in L2 (L2 to L2) seems to imply that late bilinguals can establish morphological relations between words in L2 and that morphological parsing, although not as fast and effective as in L1, can occur.

The fact that these morphological priming effects mostly occurred with cross-modal priming is somewhat surprising, given that priming effects tend to decrease in the context of cross-modal priming (HOLCOMB et al., 2005; KIYONAGA et al., 2007). However, data in the literature are based on monolingual processing. It might be that the conversion from orthographic forms to phonological representations becomes more costly when more than one language is involved. Each language has its own particular grapheme to phoneme mapping, some of which may even overlap or contrast between languages (for example, the grapheme ' $\mathrm{g}$ ' maps onto the phoneme /g/ in PB, but onto the phoneme $/ \chi /$ in Dutch). Bearing that in mind, we may perhaps think of unimodal priming in language switch trials as something that can be quite costly. Perhaps the cognitive cost of this phenomenon even carried over to priming pairs that were monolingual since non-switching trials were alternated with switching trials in the same block. In any case, it seems that morphological priming effects in both L2 and L1 are not dependent on a mere orthographical repetition effect. Although without any robust priming effect in unimodal conditions for the purpose of comparison, this conclusion remains tentative.

Different from the ERP data, the behavioral data did not show any evidence of morphological priming effects in L2. This implies that RTs and ERP measures possibly reflect different stages of word recognition, and that they may be affected differently by task-related processing strategies. N400 components are known to be sensitive to lexical properties of roots (e.g. $\checkmark$ friend) more so than to lexical properties of full word forms (e.g. friendliness) (PYLKKÄNEN et al., 2000, 2002, 2003; FRANÇA et al., 2008). Therefore, lower (or less negative) amplitudes in response to morphologically complex pairs in L2 (e.g. 
amigo-amigável ("friend-friendly")) may reflect morphological priming effects because bilinguals recognize the root embedded in the target word $(\sqrt{ }$ friend $)$ for which the meaning was already activated from when the prime was processed. Thus facilitation is due to the sustained or repeated activation of the meaning representation of the root which is repeated for primes and targets in the same language. This means that, at least, morphologically complex words can be parsed for lexical roots and derivational suffixes in L2 processing. For late bilinguals, there is probably a qualitative difference in the semantic interpretation of roots and suffixes, where the semantic interpretation of lexical roots is sustained by word form to meaning mapping, while the interpretation of derivational suffixes depends on interpreting highly predictable and rulebased meaning added to a lexical root-based meaning (e.g. . Vfriend + ly (attribute) + -ness (quality/state of) $\rightarrow$ friendliness: state of being friendlike). So-called superficial morphological processing in L2 is likely to affect subsequent processing of derivational suffixes more than lexical root to meaning mapping. This difficulty becomes apparent in higher RTs for morphologically related targets in L2, such that no facilitation effect can be observed in the RT analysis as opposed to analysis of the mean amplitudes, in which we do see a morphological priming effect. This account is in line with the Superficial Processing Hypothesis (CLAHSEN; FELSER, 2006; CLAHSEN et al., 2010).

It seems less plausible to attribute this difficulty in morphological processing to an $\mathrm{L} 1$ bias for monomorphic processing given that there is a facilitation effect for morphological priming in L1, which is confirmed both by RT and mean amplitude measures, even though, in Dutch, morphologically complex words formed by derivation are less common than words formed by compounding.

The asymmetrical switch effect predicted by the Revised Hierarchical Model (RHM) was confirmed by the behavioral data. There was a significant difference between RT values for morphologically related targets and unrelated targets for cross-modal pairs in the L1 to L2 condition. RTs for morphologically related targets were significantly higher than those for unrelated pairs. This implies that especially related meanings caused a processing cost as opposed to unrelated meanings, which is something that is well accounted for by the RHM. This model attributes a special status to the relative fragility of concept to word form links in L2 as compared to word form to concept mapping, which is a 
notion that explains the observed effects in the behavioral data well. For the ERP data, we did not observe a similar asymmetrical priming effect for the L1 to L2 condition. This can be explained if we consider once again that N400 components reflect the activation of lexical root based meaning, and that there is a difference in L2 between the semantic interpretation of roots, which is relatively easy compared to interpreting derivationally generated semantics in L2. It is exactly this grammatically constrained rule based processing that is difficult to learn for late bilinguals due to cognitive-biological limitations for language acquisition beyond the critical period.

\section{Bibliographic references}

BHATIA, T. K.; WILLIAM, C. R. Introduction. In: BHATIA, T. K.; WILLIAM, C. R. (Ed.). The Handbook of Bilingualism. Malden, MA: Blackwell Publishing, 2005.

BORODITSKY, L. Linguistic Relativity. In: NADEL, L. (Ed.). Encyclopedia of Cognitive Science. London, UK: MacMillan Press, 2003. p. 917-921.

BRYSBART, M.; DIJKSTRA, T. Changing views on word recognition in bilinguals. In: MORAIS, J.; d'YDEWALLE, G. (Ed.). Bilingualism and second language acquisition. Belgium: Royal Academes for Science and the Arts of Belgium, 2006.

BULTENA, S. Bilingual visual word recognition and lexical access. In: KROLL, J. F.; De GROOT, A. (Ed.). Handbook of bilingualism: psycholinguistic approaches. New York: Oxford University Press, 2005. p. 179-201.

CLAHSEN. H.; FELSER, C. Grammatical processing in language learners. Applied Psycholinguistics, Cambridge University Press, v. 27, p. 3-42, 2006.

CLAHSEN, H.; FELSER, C.; NEUBAUER, K.; SATO, M; SILVA, R. Morphological structure in Native and Non-Native Language Processing. Language Learning, Wiley Online Library, v. 60, p. 21-43, 2010.

DE GROOT, A. M. B. La répresentation lexico-sémantique et l'accèss lexical chez le bilingue. Psychologie Française, Elsevier, v. 43, p. 297 312, 1998. 
DE GROOT, A. M. B.; DELMAAR, P.; LUPKER, S. J. The processing of interlexical homographs in translation recognition and lexical decision: Support for non-selective access to bilingual memory. The Quarterly Journal of Experimental Psychology, Taylor \& Francis Online, v. 53, n. 2, p. 397-428-432, 2000.

DÍAZ, B.; ERDOCIA, K.; de MENEZES, R. F.; MUELLER, J. L.; SEBASTIÁN-GALLÉS, N.; LAKA, I. Electrophysiological correlates of second-language syntactic processes are related to native and second language distance regardless of age of acquisition. Frontiers in Psychology, Frontiers Media, v. 7, n.133, 2016. https://doi.org/10.3389/ fpsyg.2016.00133

DIEPENDAELE, K.; DUÑABEITUA, J. A.; MORRIS, J.; KEULEERS, E. Fast morphological effects in first and second language word recognition. Journal of Memory and Language, Elsevier, v. 64, n. 4, p. 344-358, 2011. https://doi.org/10.1016/j.jml.2011.01.003

DIJKSTRA, T.; HEUVEN, W. J. B. van. The BIA model and bilingual word recognition In: J. GRAINGER, J.; JACOBS, A. M. (Ed.). Localist connectionist approaches to human cognition. Mahwah, N.J.: Erlbaum, 1998. p. 189-225.

DIJKSTRA, T.; GRAINGER, J.; HEUVEN, W. J. B. van. Recognition of Cognates and Interlingual Homographs: The Neglected Role of Phonology. Journal of Memory and Language, Elsevier, v. 41, Issue 4, p. 496-518, 1999. https://doi.org/10.1006/jmla.1999.2654

DIJKSTRA, T.; MOSCOSO DEL PRADO MARTIN, F.; SCHULPEN, P.; SCHREUDER, R.; BAAYEN, R.H. A roommate in cream: morphological family size effects on interlingual homograph recognition. Language \& Cognition Process, Taylor \& Francis Online, v. 20, n. 1/2, p. 7-41, 2005. https://doi.org/10.1080/01690960444000124

DOM, A.; VEJA, M. De; BARBER, H. Event-related Brain Potentials Elicited by Morphological, Homographic, Orthographic, and Semantic Priming. Journal of Cognitive Neuroscience, MIT Press, v. 16, n. 4, 598608, 2004. https://doi.org/10.1162/089892904323057326

DOMINGUEZ, A.; SEGUÍ, J.; QUETOS, F. The time course of inflectional morphological priming. Linguistics, De Gruyter, v. 40, p. 235-259, 2002. 
FELDMAN, L. B. Beyond orthography and phonology: differences between inflections and derivations. Journal of Memory and Language, Elsevier, v. 33, p. 442-470, 1994.

FELDMAN, L. B.; KOSTIC, A.; BASNIGHT-BROWN, D. M.; FILIPOVIC-DURDEVIC, D.; PASTIZZO, M. J. Morphological facilitation for regular and irregular verb formations in native and non-native speakers: little evidence for two distinct mechanisms. Bilingualism: Language and Cognition, Cambridge University Press, v. 13, p. 119-135, 2009.

FRANÇA, I.; LEMLE, M; GESUALDI, A. M.; CAGY. M.; INFANTOSI. A. F. C. A neurofisiologia do acesso lexical: palavras em português. Veredas, Programa de Pós-Graduação em Linguística da UFJF, v. 12, n. 2, p. 34-49, 2008.

GARCIA, D. C. de; MAIA, M.A. R.; FRANÇA, A. I. The time course of word recognition: evidence from Brazilian Portuguese, ReVEL - Revista Virtual de Estudos da Linguagem, [s.1.], v. 10, p. 169-181, 2012.

GREEN, D. W. Mental control of the bilingual lexico-samantic system. Bilingualism: Language and Cognition, Cambridge University Press, v. 1, n. 1, p, 67-81, 1998. DOI: https://doi.org/10.1017/S1366728998000133. GROSJEAN, F. Neurolinguists, beware! The bilingual is not two monolinguals in one person. Brain and Language, 36, 3-15, 1989. https:// doi.org/10.1016/0093-934X(89)90048-5

GROSJEAN, F. Studying bilinguals: Methodological and conceptual issues. Bilingualism, Language and Cognition, Cambridge University Press, v. 1, n. 2, p.131-149, 1998. DOI: https://doi.org/10.1017/ S136672899800025X.

GROSJEAN, F. Individual bilingualism. In: ASHER, R. E. (Ed.). The encyclopaedia of language and linguistics. Oxford, UK: Pergamon Press, 1994. p. 1656-1660.

HAHNE, A.; FRIEDERICI, A. D. Processing a second language: late learners' comprehension mechanisms as revealed by event-related brain potentials. Bilingualism: Language and Cognition, Cambridge University Press, v. 4, Issue 2, p 123-141, 2001. 
HAHNE, A.; MUELLER, J. H; CLAHSEN, H. Morphological processing in a second language: Behavioural and event-related potential evidence for storage and decomposition, Journal of Cognitive Neuroscience, MIT Press, v. 18, p. 121-134, 2006. https://doi.org/10.1162/089892906775250067

HALLE, M.; MARANTZ, A. Distributed Morphology and the pieces of inflection. In: HALE, K.; KEYSER, S. J. (Ed.). The view from building 20: essays in linguistics in honor of Sylvain Bromberger. Cambridge, MA: The MIT Press, 1993. p. 111-176.

HEREDIA, R. R.; BROWN, J. M. Bilingual memory. In: BHATIA, T. K.; RITCHIE,W. C.; (Ed.). Handbook of Bilingualism. Malden, MA: Blackwell Publishers, 2004.

HOLCOMB, P. J.; ANDERSON, J.; GRAINGER, J. An electrophysiological study of cross-modal repetition priming. Psychophysiology, Wiley Online Library, v. 42, n. 5, p. 493-507, 2005. https://doi.org/10.1111/j.1469-8986.2005.00348.x

JACQUET, M.; FRENCH, R. M. The BIA++: Extending the BIA+ to a dynamical distributed connectionist framework. Bilingualism: Language and Cognition, Cambridge University Press, v. 5, n. 3, p. 202-205, 2002. https://doi.org/10.1017/S1366728902223019

KIYONAGA, K.; GRAINGER, J.; MIDGLEY, K.; HOLCOMB, P. J. Masked cross-modal repetition priming: an event-related potential investigation. Language and Cognitive Processes, Taylor \& Francis Online, v. 22, n. 3, p. 337-376, 2007. https://doi.org/10.1080/01690960600652471

KOTZ, S. A. Neurolinguistic evidence for bilingual language representation: a comparison of reaction times and event-related brain potentials. Bilingualism: Language and Cognition, Cambridge University Press, v. 4, n. 2, p. 143-154, 2001. https://doi.org/10.1017/ S1366728901000244

KOTZ, S. A.; ELSTON-GÜTTLER, K. The role of proficiency in processing categorical and associative information in the L2 as revealed by reaction times and event-related brain potentials. Journal of Neurolinguistics, Elsevier, v. 17, Issues 2/3, p. 215-235, 2004.

KOTZ, S. A.; HOLCOMB, P. J.; OSTERHOUT, L. ERPs reveal comparable syntactic sentence processing in native and non-native readers of English. Acta Psychologica, Elsevier, v. 128, n. 3, p. 514-527, 2008. https://doi.org/10.1016/j.actpsy.2007.10.003 
KROLL, J. F.; de GROOT, A. M. B. Lexical and conceptual memory in the bilingual:Mapping form to meaning in two languages. In: de GROOT, M. B.; KROLL, J. F. (Ed.). Tutorials in bilingualism. Mahwah, NJ: Erlbaum, 1997. p 169-199.

KROLL, J. F.; STEWART, E. Category interference in translation and picture naming: Evidence for asymmetric connections between bilingual memory representations. Journal of Memory and Language, Elsevier, v. 33, p. 149-174, 1994. https://doi.org/10.1006/jmla.1994.1008

KROLL, J. F.; HELL, J. G. van; TOKOWICZ, N.; GREEN, D. The revised hierarchical model: a critical review and assessment. Bilingualism: Language and Cognition, Cambridge University Press, v. 13, n. 3, p. 373-381, 2010. https://doi.org/10.1017/S136672891000009X

KUTAS, M.; FEDERMEIER, K. D. Electrophysiology reveals semantic memory use inlanguage comprehension. Trends in Cognitive Sciences, Elsevier, v, 4, n, 12, p, 463-470, 2000.

LAU, E.; PHILLIPS, C.; POEPPEL, D. A cortical network for semantics: (de)constructing the N400. Nature Reviews Neuroscience, Macmillan Publishers, v. 9, n. 12, p. 920-933, 2008. https://doi.org/10.1038/nrn2532

LEMHÖFER, K.; DIJKSTRA, T.; SCHRIEFERS, H.; BAAYEN, H. R.; GRAINGER, J.; ZWITSERLOOD, P. Native Language Influences on Word Recognition in a Second language: A Mega-Study. Journal of Experimental Psychology: Learning, Memory, and Cognition, PublMed, v. 34, p. 12-31, 2008.

LENSINK, S. E.; VERDONSCHOT, R. G.; SCHILLER, N. O. Morphological priming during language switching: an ERP study. Frontiers in Human Neuroscience, Frontiers Media, v. 8, p. 995, 2014. doi: 10.3389/fnhum.2014.00995. https://doi.org/10.3389/fnhum.2014.00995

LEWY. N.; GROSJEAN, F. Category interference in translation and picture naming: Evidence for asymmetric connections between bilingual memory representations. Journal of Memory and Language, Elsevier, v. 33, p. 149-174, 1994. https://doi.org/10.1006/jmla.1994.1008

LIPSKY, J. M. Code switching and bilingual competence. In: PARADIS M. (Ed.). Aspects of bilingualism. Columbia: Hornbeam Press, 1978. p. 250-264. 
LUCK, S. Introduction to the Event-Related Potential Technique. Cambridge: MIT, 2005.

MARANTZ, A. No escape from syntax: Don't try morphological analysis in the privacy of your own lexicon. In: ANNUAL PENN LINGUISTICS COLLOQUIUM, $21^{\text {st }}$., 1997, Pennsylvania. University of Pennsylvania Working Papers in Linguistics (PWPL), Pennsylania, v. 4, n. 2, p. 201 225, 1997.

MARANTZ, A. Generative linguistics within the cognitive neuroscience of language. The Linguistic Review, De Gruyter, v. 22, p. 429-445, 2005.

MEISEL, J. M. Getting FAT: Finiteness, agreement and tense in early grammars In: MEISEL, J. M. (Ed.). Bilingual first language acquisition: French and German grammatical development. Amsterdam: Benjamins, 1994. p. 89-130. https://doi.org/10.1075/lald.7

MUNTE, T. F.; SAY, T.; CLAHSEN, H.; SCHILTZ, K.; KUTAS, M. Decomposition of morphologically complex words in English: evidence from event-related brain potentials. Brain Research. Cognitive Brain Research Journal, PubMed, v. 7, n. 3, p. p. 241-253, Jan. 1999.

NIEDERMEYER, E.; SILVA, F. L. Electroencephalography: Basic principles. Clinical applications and related fields. 4. ed. Baltimore. Maryland: Williams \& Wilkins, 1982. p. 1258.

OSTERHOUT, L.; MCLAUGHLIN, J.; BERSICK, M. Event-related brain potentials and human language. Trends in Cognitive Sciences, New York, v. 1, n. 6, p. 203-209, Sept. 1997. https://doi.org/10.1016/S13646613(97)01073-5

PARADIS, M. The cognitive neuropsychology of bilingualism. In: de GROOT, A.; KROLL, J. (Ed.). Tutorials in bilingualism: psycholinguistic perspectives. Hillsdale, NJ.: Lawrence Erlbaum, 1997. p. 331-354.

PORTIN, M.; LEHTONEN, M.; LAINE, M. Processing of inflected nouns in late bilinguals. Applied Psycholinguistics, Oxford Academic, V. 28, p. 135-156, 2007.

PYLKKÄNEN, L.; STRINGFELLOW, A.; FLAGG, A.; MARANTZ, A. Neural response sensitive to repetition and phonotactic probability: MEG investigations of lexical access. In: BIOMAG, 2000, Espoo, Finland. Proceedings... Espoo: Helsinki University of Technology, 2000. p. 363367. 
PYLKKÄNEN, L.; GONNERMAN, L.; STRINGFELLOW, A.; MARANTZ, A. Disambiguating the source of phonological inhibition effects in lexical decision: an MEG study. New York: New York University; Lehigh University; University of California at San Diego, 2003

PYLKKÄNEN, L.; STRINGFELLOW, A.; MARANTZ, A. Neuromagnetic evidence for the timing of lexical activation: an MEG component sensitive to phonotactic probability but not to neighborhood density. Brain and Language, Elsevier, v. 81, n. 1/3, p. 666-678, 2002. https://doi.org/10.1006/brln.2001.2555

PYLKKÄNEN, L.; MARANTZ, A, Tracking the time course of word recognition with MEG, Trends in Cognitive Sciences, New York, v. 7, n. 5, p. 187-189, 2003. https://doi.org/10.1016/S1364-6613(03)00092-5

SCHRIEFERS, H.; FRIEDERICI, A.; GRAETZ, P. Inflectional and derivational morphology in the mental lexicon: Symmetries and asymmetries in repetition priming. Quarterly Journal of Experimental Psychology, ResearchGate, v. 44A, p. 373-390, 1992.

SILVA, R.; CLAHSEN, H. Morphologically complex words in L1 and L2 processing: Evidence from masked priming experiments in English. Bilingualism: Language and Cognition, Cambridge University Press, v. 11, p. 245-260, 2008.

SOTO, M. Interceptando mecanismos de alternância bilíngue: a micromodularidade revelada nos ERPs. Dissertação de mestrado, f. 185, UFRJ, Faculdade de Letras, Rio de Janeiro, 2010.

STOCKALL, L.; MARANTZ, A. A single route, full decomposition model of morphological complexity: MEG evidence. The Mental Lexicon, John Benjamins, v. 1, n. 1, p. 85-123, 2006. https://doi.org/10.1075/ ml.1.1.07sto

TANNER, D.; MCLAUGHLIN, J.; HERSCHENSOHN, J.; OSTERHOUT, L. Individual differences reveal stages of L2 grammatical acquisition: ERP evidence. Bilingualism: Language and Cognition, Cambridge University Press, v. 16, p. 367-382, 2016. https://doi. org/10.1017/S1366728912000302 
ULLMAN, M. Contributions of memory circuits to language: the declarative/procedural model. Cognition, Elsevier, v. 92, p. 231-270, 2004. https://doi.org/10.1016/j.cognition.2003.10.008

ULLMAN, M. A Cognitive neuroscience perspective on second language acquisition: the declarative/procedural model. In: SANZ, C. (Ed.). Mind and context in adult second language acquisition: methods, theory and practice. Washington D.C.: Georgetown University Press, 2005. p. 141178.

WEBER-FOX, C. M.; NEVILLE, H. Maturational Constraints on Functional Specializations for Language Processing: ERP and Behavioral Evidence in Bilingual Speakers. Journal of Cognitive Neuroscience, MIT Press, v. 8, n. 3, p. 231-256, 1996. https://doi.org/10.1162/ jocn.1996.8.3.231

WHORF, B. (Ed.). Language, thought, and reality: selected writings of Benjamin Lee Whorf. New York; London: MIT Press, 1956. 


\section{APPENDIX 1 - Stimuli list}

\begin{tabular}{|c|c|c|c|c|c|c|c|}
\hline Series & $\begin{array}{l}\mathrm{L} \\
\text { combination }\end{array}$ & $\begin{array}{l}\text { relation } \\
\text { type }\end{array}$ & modality & prime & $\begin{array}{l}\text { (gram. } \\
\text { class) }\end{array}$ & target & $\begin{array}{l}\text { (gram. } \\
\text { class) }\end{array}$ \\
\hline 1 & L1-L1 & morph. & AUD & tijd & NOUN & TIJDIG & ADJ \\
\hline 1 & L1-L1 & morph. & AUD & zorg & NOUN & ZORGELOOS & ADJ \\
\hline 1 & L1-L1 & morph. & AUD & moeder & NOUN & MOEDERLIJK & ADJ \\
\hline 1 & L1-L1 & morph. & AUD & mens & ADJ & MENSHEID & NOUN \\
\hline 1 & L1-L1 & morph. & AUD & kracht & NOUN & KRACHTIG & ADJ \\
\hline 1 & L1-L1 & morph. & AUD & voeden & VERB & VOEDZAAM & ADJ \\
\hline 1 & L1-L1 & morph. & AUD & zuiver & ADJ & ZUIVERHEID & NOUN \\
\hline 1 & L1-L1 & morph. & AUD & macht & NOUN & MACHTIG & ADJ \\
\hline 1 & L1-L1 & unrel. & AUD & zoeken & VERB & KINDEREN & NOUN \\
\hline 1 & L1-L1 & unrel. & AUD & vraag & NOUN & ARTIKEL & NOUN \\
\hline 1 & L1-L1 & unrel. & AUD & slim & NOUN & LANGZAAM & ADJ \\
\hline 1 & L1-L1 & unrel. & AUD & kerk & NOUN & PLEZIER & NOUN \\
\hline 1 & L1-L1 & unrel. & AUD & middag & NOUN & RELATIE & NOUN \\
\hline 1 & L1-L1 & unrel. & AUD & knuffel & NOUN & KLACHTEN & NOUN \\
\hline 1 & L1-L1 & unrel. & AUD & klap & NOUN & BALKON & NOUN \\
\hline 1 & L1-L1 & unrel. & AUD & arbeid & NOUN & SPINAZIE & NOUN \\
\hline 1 & L1-Hung & & AUD & licht & ADJ & AGGÓDJÁL & \\
\hline 1 & L1-Hung & & AUD & graag & ADJ & ALAPZAT & \\
\hline 1 & L1-Hung & & AUD & dorst & NOUN & ВЕКӦТӦ & \\
\hline 1 & L1-Hung & & AUD & beurs & NOUN & BESÚGÓ & \\
\hline 1 & L1-Hung & & AUD & vloer & NOUN & BÓKJÁT & \\
\hline 1 & L1-Hung & & AUD & slank & ADJ & BOLOND & \\
\hline 1 & L1-Hung & & AUD & groente & NOUN & CSAHOL & \\
\hline 1 & L1-Hung & & AUD & ketting & NOUN & CSALÁS & \\
\hline 1 & L1-Hung & & AUD & sport & NOUN & CSAPÁS & \\
\hline 1 & L1-Hung & & AUD & functie & NOUN & CSOPORT & \\
\hline 1 & L1-Hung & & AUD & metode & NOUN & CSORDA & \\
\hline 1 & L1-Hung & & AUD & kozijn & NOUN & CSUPÁN & \\
\hline 1 & L1-Hung & & AUD & knoop & NOUN & DURRAN & \\
\hline 1 & L1-Hung & & AUD & plank & NOUN & EGYIK & \\
\hline
\end{tabular}




\begin{tabular}{|c|c|c|c|c|c|c|c|}
\hline 1 & L1-Hung & & AUD & braaf & ADJ & ELHELYEZ & \\
\hline 1 & L1-Hung & & AUD & nagel & NOUN & ELILLAN & \\
\hline 2 & L2-L1 & morph. & AUD & jogo & NOUN & SPELER & NOUN \\
\hline 2 & L2-L1 & morph. & AUD & seguir & VERB & VOLGZAAM & ADJ \\
\hline 2 & L2-L1 & morph. & AUD & brilho & ADJ & GLANSLOOS & ADJ \\
\hline 2 & L2-L1 & morph. & AUD & casar & VERB & TROUWERIJ & NOUN \\
\hline 2 & L2-L1 & morph. & AUD & sentir & VERB & VOELBAAR & ADJ \\
\hline 2 & L2-L1 & morph. & AUD & fome & NOUN & HONGERIG & ADJ \\
\hline 2 & L2-L1 & morph. & AUD & chorar & VERB & HUILERIG & ADJ \\
\hline 2 & L2-L1 & morph. & AUD & culpa & NOUN & SCHULDIG & ADJ \\
\hline 2 & L2-L1 & unrel. & AUD & comprar & VERB & GESPREK & NOUN \\
\hline 2 & L2-L1 & unrel. & AUD & conselho & NOUN & BLIJVEN & VERB \\
\hline 2 & L2-L1 & unrel. & AUD & andar & VERB & STRATEN & NOUN \\
\hline 2 & L2-L1 & unrel. & AUD & morte & NOUN & STRAND & NOUN \\
\hline 2 & L2-L1 & unrel. & AUD & rotina & NOUN & VRIENDIN & NOUN \\
\hline 2 & L2-L1 & unrel. & AUD & esconder & VERB & OCHTEND & NOUN \\
\hline 2 & L2-L1 & unrel. & AUD & pato & NOUN & STERKTE & NOUN \\
\hline 2 & L2-L1 & unrel. & AUD & trato & NOUN & HORLOGE & NOUN \\
\hline 2 & L2-Hung & & AUD & quieto & ADJ & ELÉRTE & \\
\hline 2 & L2-Hung & & AUD & lima & NOUN & HOZZÁJUK & \\
\hline 2 & L2-Hung & & AUD & fechar & VERB & LEGALÁBB & \\
\hline 2 & L2-Hung & & AUD & mestre & NOUN & IDEGESÍT & \\
\hline 2 & L2-Hung & & AUD & virar & VERB & HIÁNYA & \\
\hline 2 & L2-Hung & & AUD & colo & NOUN & HIRTELEN & \\
\hline 2 & L2-Hung & & AUD & intenso & ADJ & MONDUNK & \\
\hline 2 & L2-Hung & & AUD & urso & NOUN & ELEGET & \\
\hline 2 & L2-Hung & & AUD & anular & VERB & ELTÖRPÜL & \\
\hline 2 & L2-Hung & & AUD & maçã & NOUN & HISZEN & \\
\hline 2 & L2-Hung & & AUD & teimoso & ADJ & MAGYAR & \\
\hline 2 & L2-Hung & & AUD & morder & VERB & GYÜJTI & \\
\hline 2 & L2-Hung & & AUD & pulmão & NOUN & ÁTNÉZTE & \\
\hline 2 & L2-Hung & & AUD & furo & NOUN & OLDALON & \\
\hline 2 & L2-Hung & & AUD & umido & ADJ & MOZGÁST & \\
\hline
\end{tabular}




\begin{tabular}{|c|c|c|c|c|c|c|c|}
\hline 2 & L2-Hung & & AUD & labio & NOUN & EZENTÚL & \\
\hline 3 & L1-L2 & morph. & AUD & groot & ADJ & GRANDEZA & NOUN \\
\hline 3 & L1-L2 & morph. & AUD & kleur & NOUN & CORANTE & ADJ \\
\hline 3 & L1-L2 & morph. & AUD & begin & NOUN & INICIANTE & ADJ \\
\hline 3 & L1-L2 & morph. & AUD & klaar & $\mathrm{ADJ}$ & PRONTIDÃO & NOUN \\
\hline 3 & L1-L2 & morph. & AUD & zacht & ADJ & SUAVEMENTE & NOUN \\
\hline 3 & L1-L2 & morph. & AUD & droog & ADJ & SECADOR & NOUN \\
\hline 3 & L1-L2 & morph. & AUD & woede & NOUN & RAIVOSO & ADJ \\
\hline 3 & L1-L2 & morph. & AUD & zonde & NOUN & PECADO & NOUN \\
\hline 3 & L1-L2 & unrel. & AUD & alleen & ADJ & POSSÍVEL & ADJ \\
\hline 3 & L1-L2 & unrel. & AUD & niets & NOUN & DIFERENTE & ADJ \\
\hline 3 & L1-L2 & unrel. & AUD & park & NOUN & BARATO & ADJ \\
\hline 3 & L1-L2 & unrel. & AUD & scherm & NOUN & PRÉDIO & NOUN \\
\hline 3 & L1-L2 & unrel. & AUD & wetten & NOUN & VESTIDO & NOUN \\
\hline 3 & L1-L2 & unrel. & AUD & rivier & NOUN & CURIOSO & ADJ \\
\hline 3 & L1-L2 & unrel. & AUD & rust & NOUN & GELADO & ADJ \\
\hline 3 & L1-L2 & unrel. & AUD & winnen & VERB & GRÁVIDA & ADJ \\
\hline 3 & L1-Hung & & AUD & eigen & ADJ & ESÖÁLLÓ & \\
\hline 3 & L1-Hung & & AUD & kies & VERB & FEJEZET & \\
\hline 3 & L1-Hung & & AUD & keuken & NOUN & FEKHELY & \\
\hline 3 & L1-Hung & & AUD & geest & NOUN & FÉLCIPÖ & \\
\hline 3 & L1-Hung & & AUD & nuttig & ADJ & FOGDOS & \\
\hline 3 & L1-Hung & & AUD & beker & NOUN & FÖLDÚT & \\
\hline 3 & L1-Hung & & AUD & schrift & NOUN & FÜGGÖNY & \\
\hline 3 & L1-Hung & & AUD & blond & ADJ & FÚJTAK & \\
\hline 3 & L1-Hung & & AUD & type & NOUN & FÜLLEDT & \\
\hline 3 & L1-Hung & & AUD & avontuur & NOUN & GÉPÁGY & \\
\hline 3 & L1-Hung & & AUD & belg & NOUN & GYÁVÁVÁ & \\
\hline 3 & L1-Hung & & AUD & vest & NOUN & GYENGE & \\
\hline 3 & L1-Hung & & AUD & vlinder & NOUN & GYERMEK & \\
\hline 3 & L1-Hung & & AUD & erven & VERB & GYÖTÖR & \\
\hline 3 & L1-Hung & & AUD & pols & NOUN & HADIÜZEM & \\
\hline 3 & L1-Hung & & AUD & moraal & NOUN & HAJÓJÁT & \\
\hline
\end{tabular}




\begin{tabular}{|c|c|c|c|c|c|c|c|}
\hline 4 & L2-L2 & morph. & AUD & conta & NOUN & CONTADOR & NOUN \\
\hline 4 & L2-L2 & morph. & AUD & alegre & ADJ & ALEGRIA & NOUN \\
\hline 4 & L2-L2 & morph. & AUD & dúvida & NOUN & DUVIDOSO & ADJ \\
\hline 4 & L2-L2 & morph. & AUD & cabeça & NOUN & CABEÇADA & NOUN \\
\hline 4 & L2-L2 & morph. & AUD & parar & VERB & PARADA & NOUN \\
\hline 4 & L2-L2 & morph. & AUD & correr & VERB & CORRERIA & NOUN \\
\hline 4 & L2-L2 & morph. & AUD & ácido & ADJ & ACIDEZ & NOUN \\
\hline 4 & L2-L2 & morph. & AUD & cansar & VERB & CANSADO & ADJ \\
\hline 4 & L2-L2 & unrel. & AUD & grupo & NOUN & JAQUETA & NOUN \\
\hline 4 & L2-L2 & unrel. & AUD & letra & NOUN & MOCHILA & NOUN \\
\hline 4 & L2-L2 & unrel. & AUD & amanhã & NOUN & ESCUTAR & VERB \\
\hline 4 & L2-L2 & unrel. & AUD & selo & NOUN & FELIZES & ADJ \\
\hline 4 & L2-L2 & unrel. & AUD & raiz & NOUN & BONITO & ADJ \\
\hline 4 & L2-L2 & unrel. & AUD & queijo & NOUN & PALAVRA & NOUN \\
\hline 4 & L2-L2 & unrel. & AUD & burro & ADJ & SEGURO & ADJ \\
\hline 4 & L2-L2 & unrel. & AUD & joelho & NOUN & ESTRANHO & ADJ \\
\hline 4 & L2-Hung & & AUD & idéia & NOUN & LESÜTÖTT & \\
\hline 4 & L2-Hung & & AUD & topo & NOUN & LESZID & \\
\hline 4 & L2-Hung & & AUD & mesa & NOUN & LEVÉLSZÓ & \\
\hline 4 & L2-Hung & & AUD & natural & ADJ & LEZUHAN & \\
\hline 4 & L2-Hung & & AUD & triste & ADJ & LÖKÖTT & \\
\hline 4 & L2-Hung & & AUD & praga & NOUN & LOVASSÁG & \\
\hline 4 & L2-Hung & & AUD & dama & NOUN & MACSKÁM & \\
\hline 4 & L2-Hung & & AUD & lençol & NOUN & MEGCSAL & \\
\hline 4 & L2-Hung & & AUD & álcool & NOUN & IKONRA & \\
\hline 4 & L2-Hung & & AUD & pera & NOUN & KITÉRTEK & \\
\hline 4 & L2-Hung & & AUD & ralo & NOUN & EGYMÁS & \\
\hline 4 & L2-Hung & & AUD & rastro & NOUN & EGYBEN & \\
\hline 4 & L2-Hung & & AUD & calar & VERB & KUTATÁST & \\
\hline 4 & L2-Hung & & AUD & mover & VERB & SZÁJÁBA & \\
\hline 4 & L2-Hung & & AUD & algebra & NOUN & OKOKBÓL & \\
\hline 4 & L2-Hung & & AUD & irritar & VERB & KICSIT & \\
\hline 5 & L1-L1 & morph. & WR & land & NOUN & LANDELIJK & ADJ \\
\hline
\end{tabular}




\begin{tabular}{|c|c|c|c|c|c|c|c|}
\hline 5 & L1-L1 & morph. & WR & werken & VERB & WERKELOOS & ADJ \\
\hline 5 & L1-L1 & morph. & WR & wassen & VERB & WASSERIJ & NOUN \\
\hline 5 & L1-L1 & morph. & WR & slapen & VERB & SLAPERIG & ADJ \\
\hline 5 & L1-L1 & morph. & WR & pijn & NOUN & PIJNLIJK & ADJ \\
\hline 5 & L1-L1 & morph. & WR & zicht & NOUN & ZICHTBAAR & ADJ \\
\hline 5 & L1-L1 & morph. & WR & zuiden & NOUN & ZUIDELIJK & ADJ \\
\hline 5 & L1-L1 & morph. & WR & vrede & NOUN & VREDIG & ADJ \\
\hline 5 & L1-L1 & unrel. & WR & nieuw & ADJ & RECHTER & NOUN \\
\hline 5 & L1-L1 & unrel. & WR & fietsen & VERB & VERHAAL & NOUN \\
\hline 5 & L1-L1 & unrel. & WR & klein & ADJ & ZILVER & NOUN \\
\hline 5 & L1-L1 & unrel. & WR & lenen & VERB & DOCHTER & NOUN \\
\hline 5 & L1-L1 & unrel. & WR & komen & VERB & WONDER & NOUN \\
\hline 5 & L1-L1 & unrel. & WR & geheim & NOUN & WERELD & NOUN \\
\hline 5 & L1-L1 & unrel. & WR & katoen & NOUN & BELOFTE & NOUN \\
\hline 5 & L1-L1 & unrel. & WR & eten & VERB & HERFST & NOUN \\
\hline 5 & L1-Hung & & WR & plan & NOUN & HATÁROS & \\
\hline 5 & L1-Hung & & WR & donker & ADJ & HÉTALVÓ & \\
\hline 5 & L1-Hung & & WR & donker & ADJ & HÉTALVÓ & \\
\hline 5 & L1-Hung & & WR & luxe & NOUN & HITELBE & \\
\hline 5 & L1-Hung & & WR & avond & NOUN & HOZTUNK & \\
\hline 5 & L1-Hung & & WR & dalen & VERB & HULLADÉK & \\
\hline 5 & L1-Hung & & WR & focus & NOUN & IDÖJÁRÁS & \\
\hline 5 & L1-Hung & & WR & slecht & ADJ & IGAZÁN & \\
\hline 5 & L1-Hung & & WR & tempel & NOUN & IGAZGATÓ & \\
\hline 5 & L1-Hung & & WR & kist & NOUN & ILLETVE & \\
\hline 5 & L1-Hung & & WR & balen & VERB & IMÁDNI & \\
\hline 5 & L1-Hung & & WR & spin & NOUN & IRÁNYÁT & \\
\hline 5 & L1-Hung & & WR & touw & NOUN & ISMERT & \\
\hline 5 & L1-Hung & & WR & slap & ADJ & ISZÁKOS & \\
\hline 5 & L1-Hung & & WR & klep & NOUN & JÁTSZIK & \\
\hline 5 & L1-Hung & & WR & zweten & VERB & JÉGNEK & \\
\hline 6 & L2-L1 & morph. & WR & fala & NOUN & SPRAAKZAAM & \\
\hline 6 & L2-L1 & morph. & WR & viver & VERB & LEVENDIG & \\
\hline
\end{tabular}




\begin{tabular}{|c|c|c|c|c|c|c|}
\hline 6 & L2-L1 & morph. & WR & sonho & NOUN & DROMERIG \\
\hline 6 & L2-L1 & morph. & WR & perigo & NOUN & GEVAARLIJK \\
\hline 6 & L2-L1 & morph. & WR & sabor & NOUN & SMAKELIJK \\
\hline 6 & L2-L1 & morph. & WR & dano & VERB & SCHADELIJK \\
\hline 6 & L2-L1 & morph. & WR & luta & NOUN & VECHTER \\
\hline 6 & L2-L1 & morph. & WR & quebrar & VERB & BREEKBAAR \\
\hline 6 & L2-L1 & unrel. & WR & semana & NOUN & LASTIG \\
\hline 6 & L2-L1 & unrel. & WR & cara & NOUN & DENKEN \\
\hline 6 & L2-L1 & unrel. & WR & sentido & NOUN & WINTER \\
\hline 6 & L2-L1 & unrel. & WR & vigor & NOUN & STOELEN \\
\hline 6 & L2-L1 & unrel. & WR & pele & NOUN & BENIEUWD \\
\hline 6 & L2-L1 & unrel. & WR & lápis & NOUN & GRAPPIG \\
\hline 6 & L2-L1 & unrel. & WR & falha & NOUN & TEVREDEN \\
\hline 6 & L2-L1 & unrel. & WR & honrado & ADJ & LAARZEN \\
\hline 6 & L2-Hung & & WR & centro & NOUN & MEGLÉP \\
\hline 6 & L2-Hung & & WR & arte & NOUN & MEGMENTI \\
\hline 6 & L2-Hung & & WR & valer & ADJ & MEGÖRÜL \\
\hline 6 & L2-Hung & & WR & simples & ADJ & MEGVESZ \\
\hline 6 & L2-Hung & & WR & ativo & ADJ & MIKÖZBEN \\
\hline 6 & L2-Hung & & WR & raça & NOUN & NEKIRONT \\
\hline 6 & L2-Hung & & WR & pano & NOUN & NINCSEN \\
\hline 6 & L2-Hung & & WR & lago & NOUN & NÖVÉNY \\
\hline 6 & L2-Hung & & WR & calma & ADJ & NYAGGAT \\
\hline 6 & L2-Hung & & WR & maré & NOUN & OLDALAK \\
\hline 6 & L2-Hung & & WR & brisa & NOUN & PÉLDÁUL \\
\hline 6 & L2-Hung & & WR & pintor & NOUN & ROMJAI \\
\hline 6 & L2-Hung & & WR & honesto & ADJ & SZAVAIT \\
\hline 6 & L2-Hung & & WR & garra & NOUN & TOVÁBBI \\
\hline 6 & L2-Hung & & WR & cabra & NOUN & LÁTVÁNY \\
\hline 6 & L2-Hung & & WR & cenoura & NOUN & LEÁNYKA \\
\hline 7 & L1-L2 & morph. & WR & openen & VERB & ABERTURA \\
\hline 7 & L1-L2 & morph. & WR & snel & ADJ & RAPIDEZ \\
\hline 7 & L1-L2 & morph. & WR & vrij & ADJ & LIVREMENTE \\
\hline
\end{tabular}




\begin{tabular}{|c|c|c|c|c|c|c|c|}
\hline 7 & L1-L2 & morph. & WR & lelijk & ADJ & FEIOSO & \\
\hline 7 & L1-L2 & morph. & WR & einde & NOUN & FINALMENTE & \\
\hline 7 & L1-L2 & morph. & WR & lachen & NOUN & RISADA & \\
\hline 7 & L1-L2 & morph. & WR & meten & VERB & MEDIÇÃO & \\
\hline 7 & L1-L2 & morph. & WR & traag & ADJ & LENTIDÃO & \\
\hline 7 & L1-L2 & unrel. & WR & zitten & VERB & LARANJA & \\
\hline 7 & L1-L2 & unrel. & WR & groen & ADJ & FÉRIAS & \\
\hline 7 & L1-L2 & unrel. & WR & stappen & VERB & SURPRESA & \\
\hline 7 & L1-L2 & unrel. & WR & gang & NOUN & LEVANTAR & \\
\hline 7 & L1-L2 & unrel. & WR & leider & NOUN & ESCOVA & \\
\hline 7 & L1-L2 & unrel. & WR & kast & NOUN & CORUJA & \\
\hline 7 & L1-L2 & unrel. & WR & staal & NOUN & OMBROS & \\
\hline 7 & L1-L2 & unrel. & WR & doel & NOUN & CARENTE & \\
\hline 7 & L1-Hung & & WR & muziek & NOUN & & \\
\hline 7 & L1-Hung & & WR & lijst & NOUN & & \\
\hline 7 & L1-Hung & & WR & thuis & NOUN & & \\
\hline 7 & L1-Hung & & WR & klant & NOUN & & \\
\hline 7 & L1-Hung & & WR & export & NOUN & & \\
\hline 7 & L1-Hung & & WR & boete & NOUN & & \\
\hline 7 & L1-Hung & & WR & acteur & NOUN & & \\
\hline 7 & L1-Hung & & WR & grens & NOUN & & \\
\hline 7 & L1-Hung & & WR & tegels & NOUN & & \\
\hline 7 & L1-Hung & & WR & schaap & NOUN & & \\
\hline 7 & L1-Hung & & WR & drop & NOUN & & \\
\hline 7 & L1-Hung & & WR & koorts & NOUN & & \\
\hline 7 & L1-Hung & & WR & happen & VERB & & \\
\hline 7 & L1-Hung & & WR & spek & NOUN & & \\
\hline 7 & L1-Hung & & WR & rommel & NOUN & & \\
\hline 7 & L1-Hung & & WR & leugen & NOUN & & \\
\hline 8 & L2-L2 & morph. & WR & fraco & ADJ & FRAQUEZA & NOUN \\
\hline 8 & L2-L2 & morph. & WR & corpo & NOUN & CORPORAL & ADJ \\
\hline 8 & L2-L2 & morph. & WR & peso & NOUN & PESADO & ADJ \\
\hline 8 & L2-L2 & morph. & WR & doce & ADJ & DOÇURA & NOUN \\
\hline
\end{tabular}




\begin{tabular}{|c|c|c|c|c|c|c|c|}
\hline 8 & L2-L2 & morph. & WR & espaço & NOUN & ESPACIAL & ADJ \\
\hline 8 & L2-L2 & morph. & WR & louco & ADJ & LOUCURA & NOUN \\
\hline 8 & L2-L2 & morph. & WR & coragem & NOUN & CORAJOSO & ADJ \\
\hline 8 & L2-L2 & morph. & WR & fixar & VERB & FIXAÇÃO & NOUN \\
\hline 8 & L2-L2 & unrel. & WR & verão & NOUN & PEQUENO & ADJ \\
\hline 8 & L2-L2 & unrel. & WR & difícil & ADJ & ESPERAR & VERB \\
\hline 8 & L2-L2 & unrel. & WR & capa & NOUN & SORVETE & NOUN \\
\hline 8 & L2-L2 & unrel. & WR & inverno & NOUN & FAMOSO & ADJ \\
\hline 8 & L2-L2 & unrel. & WR & passo & NOUN & DESENHO & VERB \\
\hline 8 & L2-L2 & unrel. & WR & roda & NOUN & COELHOS & NOUN \\
\hline 8 & L2-L2 & unrel. & WR & anual & ADJ & PREGUIÇA & NOUN \\
\hline 8 & L2-L2 & unrel. & WR & horrível & ADJ & TECIDO & NOUN \\
\hline 8 & L2-Hung & & WR & pessoal & ADJ & JOBBRA & \\
\hline 8 & L2-Hung & & WR & estudo & NOUN & KERESNI & \\
\hline 8 & L2-Hung & & WR & lixo & NOUN & KÉSZÜLT & \\
\hline 8 & L2-Hung & & WR & festa & NOUN & KIDOBVA & \\
\hline 8 & L2-Hung & & WR & missão & NOUN & KIFEJLÉS & \\
\hline 8 & L2-Hung & & WR & cópia & NOUN & KINYOMJA & \\
\hline 8 & L2-Hung & & WR & anel & NOUN & KIRÚGÁS & \\
\hline 8 & L2-Hung & & WR & resto & NOUN & KITÖMÖTT & \\
\hline 8 & L2-Hung & & WR & dança & NOUN & KORHOL & \\
\hline 8 & L2-Hung & & WR & ladrão & NOUN & KÖZELI & \\
\hline 8 & L2-Hung & & WR & nota & NOUN & KURUZSLÓ & \\
\hline 8 & L2-Hung & & WR & tonto & ADJ & KUTATÓ & \\
\hline 8 & L2-Hung & & WR & selva & NOUN & KUTATUNK & \\
\hline 8 & L2-Hung & & WR & raso & ADJ & KUTYAGOL & \\
\hline 8 & L2-Hung & & WR & cela & NOUN & LÁBAZAT & \\
\hline 8 & L2-Hung & & WR & bagunça & NOUN & ZUHANÁS & \\
\hline
\end{tabular}




\section{APPENDIX 2 - Suffix distribution}

\begin{tabular}{|c|c|c|c|c|c|}
\hline L1 & suffix & n. & L2 & suffix & n. \\
\hline & IG & 8 & & OR & 2 \\
\hline & LOOS & 3 & & IA & 2 \\
\hline & LIJK & 7 & & OSO & 4 \\
\hline & ER & 2 & & ADA & 3 \\
\hline & ERIJ & 2 & & EZ & 2 \\
\hline & BAAR & 3 & & ADO & 3 \\
\hline & ERIG & 3 & & EZA & 2 \\
\hline & HEID & 2 & & ANTE & 2 \\
\hline & ZAAM & 3 & & ENTO & 1 \\
\hline Total & 9 types & & & ÃO & 2 \\
\hline & & & & MENTE & 2 \\
\hline & & & & $\mathrm{AL}$ & 2 \\
\hline & & & & URA & 3 \\
\hline & & & & IDÃO & 2 \\
\hline & & & total & 14 types & \\
\hline
\end{tabular}




\section{APPENDIX 3 - Autobiographical information about the participants}

\begin{tabular}{|c|c|c|c|c|c|c|c|c|c|c|}
\hline no. & age & AoA & total & learning setting & context of use & stay in & education & \multicolumn{3}{|c|}{ other languages } \\
\hline 1 & 39 & 26 & 13 & formal(1/2yr) & home/fam/social/work & 9 & superior & English & \multicolumn{2}{|c|}{ Spanish (interm) } \\
\hline 2 & 45 & 32 & 13 & Contact & home/fam/social/work & 9 & superior & English & \multicolumn{2}{|c|}{ French (intermed) } \\
\hline & & & & & & & & \multicolumn{2}{|c|}{ Alemão (interm), } & Spanish \\
\hline 3 & 28 & 23 & 5 & formal (1 yr) & work/social/home(4 yrs) & 4 & superior & French, & Spanish, & English \\
\hline 4 & 39 & 21 & 18 & formal (1/2yrs) & work/social & 8 & superior & English, & \multicolumn{2}{|c|}{ Spanish (interm) } \\
\hline 5 & 36 & 25 & 11 & contact & work $(50 \%) / \operatorname{social}(80 \%)$ & 9 & superior & English, & French, & Spanish \\
\hline & & & & & & & & \multicolumn{3}{|c|}{ German(intermed), } \\
\hline 6 & 33 & 24 & 9 & contact & home/fam/social/work & 6 & superior & Spanish, & English, & French \\
\hline 7 & 41 & 29 & 12 & contact & home/fam/social/work & 5 & superior & English, & Spanish, & alemao \\
\hline 8 & 25 & 21 & 4 & contact & fam/work $(50 \%) /$ social & 4 & superior & French, & German, & English \\
\hline 9 & 32 & 25 & 7 & formal(1/2yrs) & home/fam/social/work & 7 & superior & English & & \\
\hline 10 & 34 & 23 & 11 & formal(2yr) & home/fam/social/work & 4 & superior & English & & \\
\hline 11 & 48 & 28 & 20 & contact & work/social $(50 \%) /$ co & 9 & cient.prep. & German, & French, & English \\
\hline 12 & 33 & 23 & 10 & contact & home/work/social & 4,5 & superior & English, & German, & \\
\hline 13 & 26 & 21 & 5 & contact/self study & home/work/social & 4 & superior & English & \multicolumn{2}{|c|}{ French(intermed) } \\
\hline 14 & 35 & 21 & 14 & contato & & 7 & superior & Spanish, & English, & \\
\hline 15 & 42 & 31 & 11 & formal(2yrs) & home/work/fam/social & 4 & superior & German, & French, & English \\
\hline 16 & 35 & 22 & 13 & formal( $1 / 2 y r)$ & home/fam/social/work & 9 & superior & English, & Spanish & \\
\hline 17 & 29 & 24 & 5 & formal & home/fam/social/work & 4 & superior & English, & French, & alemao \\
\hline 18 & 41 & 26 & 15 & contact & home/fam/social/work & 15 & cient.prep. & English, & Spanish & (intermed) \\
\hline
\end{tabular}




\section{APPENDIX 4 -Proficiency judgment}

\subsection{Questionnaire}

\section{Pronunciation:}

A. On a scale from 1 to 5 , how would you rate the participants' speech:

1. you almost do not notice he/she is a foreigner, only hearing after a few sentence, paying a lot of attention;

2. you notice he or she is a foreigner, but she/he sounds like us;

3. Portuguese can be understood well, but the foreign accent is very clear;

4. The accent is so strong that it sometimes hinders comprehension of a few words;

5. The accent stops me from understanding.

B. The accent:

1. Marks only a few specific;

2. Marks the whole speech;

3. Gets in the way of communication.

\section{Vocabulary:}

C. The participant used:

1. a wide variety of words;

2. simple but adequate words;

3 . words that were not adequate for the context.

D. The participant

1. has vocabulary to name specific sites and objects in a room;

2. has vocabulary to name objects and action, and when necessary, paraphrases;

3. has a limited vocabulary, repeating the same words, and paraphrasing, occasionally using Dutch.

\section{Fluency:}

E. The participant's speech:

1. flows freely, resulting in clear comprehension;

2. generally flows, with a few pauses during which the participants tries to structure the message;

3. does not flow, many pauses and hesitation to structure the message, resulting in difficult comprehension for the listener.

\section{Structure:}

F. Sentence structure:

1. is complete;

2. is usually complete, sometimes a preposition or some connection is missing;

3. Is broken, sometimes verb subject or complement, is absent from the language. 
G. The participant used correct verbal inflection:
1. varies;
2. simple, with a little variation;
3. simple, with a little variation, with some errors;
4. simple, with many errors;
5.practically did not carry out verbal inflection.

H. The participant carries out agreement:
1. without any mistakes;
2. with a few mistakes;
3. made same constant errors, but he/she corrected himself;
4. got more wrong than right;
5.did not carry out any agreement.

\subsection{Assessment}

\begin{tabular}{|c|c|c|c|c|}
\hline \multirow{2}{*}{ participant } & pronunciation & vocabulary & fluency & structure \\
\cline { 2 - 5 } & \multicolumn{4}{|c|}{ points/total } \\
\hline 1 & $2,7 / 3$ & $2,8 / 3$ & $2,7 / 3$ & $4,6 / 5$ \\
\hline 2 & $2,8 / 3$ & $2,2 / 3$ & $2,3 / 3$ & $3,7 / 5$ \\
\hline 3 & $2,8 / 3$ & $2,3 / 3$ & $2,7 / 3$ & $4,9 / 5$ \\
\hline 4 & $2,9 / 3$ & $2,5 / 3$ & $2,3 / 3$ & $4,6 / 5$ \\
\hline 5 & $2 / 3$ & $1,7 / 3$ & $2 / 3$ & $2,2 / 5$ \\
\hline 6 & $2,8 / 3$ & $2,8 / 3$ & $2,7 / 3$ & $4,9 / 5$ \\
\hline 7 & $1,8 / 3$ & $1,5 / 3$ & $1,5 / 3$ & $2,9 / 5$ \\
\hline 8 & $1,9 / 3$ & $2,4 / 3$ & $2 / 3$ & $3,3 / 5$ \\
\hline 9 & $1,9 / 3$ & $2,3 / 3$ & $2,3 / 3$ & $4,4 / 5$ \\
\hline 10 & $2,5 / 3$ & $2,5 / 3$ & $2,3 / 3$ & $4,2 / 5$ \\
\hline 11 & $2,1 / 3$ & $2,7 / 3$ & $2 / 3$ & $4,2 / 5$ \\
\hline 12 & $1,8 / 3$ & $2,3 / 3$ & $2 / 3$ & $3,7 / 5$ \\
\hline 13 & $2 / 3$ & $2 / 3$ & $1,7 / 3$ & $3,3 / 5$ \\
\hline 14 & $2 / 3$ & $2 / 3$ & $2 / 3$ & $3,3 / 5$ \\
\hline 15 & $2 / 3$ & $1,8 / 3$ & 1,7 & $3 / 5$ \\
\hline 16 & $2,6 / 3$ & $2,7 / 3$ & $2,7 / 3$ & $4,2 / 5$ \\
\hline 17 & $3 / 3$ & $2,8 / 3$ & $2,3 / 3$ & $4,6 / 5$ \\
\hline & & & & \\
\hline & & & & \\
\hline & & & & \\
\hline
\end{tabular}

